\title{
An Action Research on the Long-Term Implementation of an Engineering-centered PjBL of Sustainable Energy in a Rural Middle School
}

\author{
Chin-Sung Chen ${ }^{1}$, Jing-Wen Lin',** \\ 1 Graduate Institute of Science Education, National Dong-Hwa University, TAIWAN; savasong@gmail.com \\ 2 Department of Science Education, National Taipei University of Education, TAIWAN; \\ jwlin@mail.ntue.edu.tw \\ * Correspondence: jwlin@mail.ntue.edu.tw
}

\begin{abstract}
Background: Due to the high proportion of disadvantaged students in a rural school in Taiwan and the gap between students' concepts and practices of environmental protection and sustainable energy, four science and mathematics teachers in this school planned an engineeringcentered PjBL of sustainable energy curriculum in a Makers Club to enhance students' creativity, engineering technical skills, practices of environmental protection and sustainable energy, and learning attitudes; (2) Methods: This study is four-year action research. Teachers and students initiated the idea from rebuilding an old fan in a classroom; (3) Results: The students in the Makers Club improved their engineering technical skills and created various green-power generation devices (evolved from ventilation ball generator, hydropower, ocean current power generators to tiny, 3Dprinting wind power generators). They turned environmental protection and sustainable energy concepts into actions during practices and won awards from science and engineering fairs every year. This creative and supportive atmosphere spread from the club to the whole school and improved the students' practices of environmental protection and learning attitudes after long-term implementation; (4) Conclusions: The design principles of the engineering-centered PjBL of sustainable energy curriculum played a critical role and were outlined at the end of the study.
\end{abstract}

Keywords: Engineering education; Engineering-centered PjBL; Power generation systems; Sustainable energy; Sustainability

\section{Introduction}

This study was conducted in a rural middle school, Longevity Junior High School (anonym), in Eastern Taiwan. Many children in rural areas are low-economic backgrounds; they lack family education resources and are usually overlooked by educational policies. Therefore, these children cannot obtain better educational achievement [1] and held negative learning attitudes toward learning. As a result, it is common for grassroots charity groups to help these disadvantaged students and propagandize the organization's ideals to teachers and students. The Tzu Chi Foundation, an NGO organization that has been promoting environmental sustainability in Taiwan for more than 30 years [2-4], is the most active and down-to-earth of these charity groups. On the other hand, humans' excessive use of fossil fuel since the industrial revolution, which has brought many conveniences, has caused global warming and abnormal climate $[5,6]$. As a small island in a subtropical area, Taiwan is easily influenced by extreme climate [7, 8]. Therefore, the government in Taiwan recognized the energy problem as a vital livelihood issue for environmental sustainability and actively integrated this issue into various subject contents [9]. 
Accordingly, Longevity Junior High School invites the Tzu Chi Foundation to its campus every semester to promote the ideals of "Environmental sustainability, environmental protection, love the earth" to improve students' ideas of sustainable energies and do something positive for the environment. However, after a long term of implementation, mathematics and science teachers have observed that while students generally possessed the ideas of green energy and understood sustainable energy, they lacked opportunities for practice and actual actions.

Even though students in rural areas lag in academic achievements, many students have problem-solving abilities and are interested in hands-on practices. School extracurricular clubs are suitable for integrating sustainable energy and carbon reduction. Therefore, four mathematics and science teachers, including the first author of this study, established a Makers Club on campus in the 2015 school year. These teachers integrated global warming and environmental sustainability into the curriculum and encouraged students to carry out sustainable energy project-based learning (PjBL). As the school's prior environmental education curricula lean toward promoting concepts, the teachers hoped that students could make connections between green energy knowledge and engineering education while engaging hands-on activities to learn how to apply environmental protection concepts into everyday life. They also hoped that the curricula established by the Makers Club could be formally adopted into the school's curricula.

\subsection{Engineering-centered PjBL}

$\mathrm{PjBL}$ has become one of the most widely adopted innovative teaching strategies for facing future challenges [10]. Mills and Treagust [11] pointed out that PjBL is the teaching strategy centered around students and focuses on interdisciplinary comprehension and application. The PjBL curriculum has a five-phase implementation process: preparation, implementation, presentation, competition, and feedback. The implementation and competition stages have a significant impact on students' engineering learning and creativity, and the presentation and feedback stages internalize learning to enhance learning effectiveness [12]. This model provides students with clear steps for learning and assists teachers in designing and operating teaching programs. PjBL can be used to solve everyday problems and is suitable for the professional reality of engineering education. It also enacts cooperative learning. Krajcik and Czerniak [13] believed that PjBL offers a unique learning environment to explore a phenomenon from driving questions that integrate science and engineering practices and, finally, create products to solve problems. PjBL in school is often carried out through interdisciplinary curricula to promote students' active engagement in science and engineering practices [14, 15]. In this study, we applied PjBL to address the interdisciplinary issue of sustainable energy, emphasizing the engineering technical skills involved; hence engineering-centered PjBL was used to refer to such a teaching strategy.

There is a significant positive correlation among students' attitudes toward problemsolving, knowledge application, thinking skills [16], and even critical thinking and multiple intelligence [17]. This method helps students carry out their practices in groups and links students and their life experiences to help them see engineering as an essential technical work [18]. The use of brainstorming during a group's cooperative learning leads to various subjects being intertwined [19]. Students can enhance their familiarity with engineering technologies and inspire their creativity [20]; their actual problem-solving ability is another facet of inspiring students' creativity [21]. Furthermore, PjBL inspires low economic background students' learning interests and positive attitudes [22].

\subsection{Engineering Technical Skills and Creativity}

Today's competitive environment demand that engineers possess engineering hard skills and soft skills [23]. Hard skills mainly refer to engineering technical skills. With different technologies of product development, the emphasis on the direction is also different, for examples, Arduino, Andrio, programming. Soft skills are the extra skills required by 
engineers to increase employability (e.g., communication, collaboration). Creativity is one dimension while measuring the presence of soft skills [24, 25].

The content of engineering technical skills varies with different projects, tasks, and professions. Scholars recommend using authentic assessments to assess the engineering technical skills in students' learning process or product. Authentic assessments employ various assessment strategies, including performance assessments, criterion-referenced assessments, systematic observations by teachers, peers, students themselves, portfolios, and journals. These are all directly related to the intended learning outcomes, for instance, what specific behaviors must be done and the conditions under which the task is performed [26]. At the beginning of the project, the four teachers in this study set learning objectives for the year. The project outcomes were expected to use the engineering technical skills taught in the preparation phase of the PjBL but not exclusively.

It is difficult to establish objective criteria to assess creativity. The basic and widely accepted definition of creativity has two characteristics: the product of the creative process must be innovative, and the product must be considered appropriate or valuable for the task [27]. Epstein, Schmidt and Warfel [28] argued that creativity is related to four core cognitive abilities. (a) capturing dreams and daydreams as a source of creativity, finding places and times where new ideas can be easily observed and preserved, (b) challenging complex problems and tasks and trying new actions and approaches, (c) broadening things in new ways, and (d) regularly changing the physical and social environment.

Methods for evaluating creativity should be comprehensive and diverse. Hocevar and Bachelor [29] noted that evaluating creativity can include self-reported creative activities or achievements, evaluations by others, and evaluations of products or works. Yang, Lee, Hong, and Lin [30] also emphasized the importance of classroom observations and case teacher interviews obtained from additional qualitative data analysis (e.g., promoting associative thinking, sharing impressive ideas, reviewing and critiquing group presentations and products) and identified supportive instructional strategies for developing students' creative science thinking. The creativity framework and qualitative measures in this study are consistent with the characteristics proposed by Hennessey and Amabile [27] and Epstein et al [28].

\subsection{Learning attitudes}

Attitudes are composed of emotions, cognitions, and intentions [31]. Attitudes can be viewed as a particular person's personal beliefs [32] and may be influenced by various factors. Factors that influence students' learning attitudes include their teachers, parents, and peers- with the teacher's teaching strategies and learning environment being the most significant [33]. Students translate positive classroom experiences into positive attitudes and learning efforts, thus influencing their ultimate academic performance [34]. Therefore, teachers must create positive classroom experiences for student learning. Research often takes a qualitative approach to understanding which experiences influence students' positive attitudes toward learning, for examples, Lee [35] adopted qualitative interview and understood the importance of education, finding classroom learning as useful, demonstration of learning behavior in and outside the classroom, and future aspirations to enroll in university are positive experience related to Qatari students' learning attitudes. Tyson [36] collected data in an ethnographic study, suggesting that Black students' schooling experiences, particularly achievement outcomes, play a central role in developing attitudes toward learning. Students who experienced academic failure were more likely than students who did not experience an intellectual inability to express negative learning attitudes directly related to their achievement experiences. Students' negative statements about learning reflected their desire to avoid further incidents of failure.

Longevity Junior High School's four mathematics and science teachers have observed the above school problem. They established an energy sustainability project Makers Club on campus, and hoped to guide students to develop creative ideas, and developing a multi-faceted, hands-on, sustainable energy curriculum using the PjBL learning 
model to establish the foundations of the engineering education curriculum. It is hoped that the engineering-centered PjBL approach will allow students to explore the importance of environmental sustainability through hands-on thinking and inquiry, thereby enhancing students' engineering technical skills and stimulating their creativity. It is expected that the concept of environmental sustainability will be turned into action and practice and that students' creativity and attitudes toward learning will be inspired. The specific questions of this study are as follows:

1. What was the process of implementing the engineering-centered PjBL of sustainable energy from the 2015-2018 school years?

2. How does engineering-centered PjBL of sustainable energy influence students' development of creativity and engineering technical skills in the Makers Club?

3. How does engineering-centered PjBL of sustainable energy enable rural students to turn the concept of green energy sustainability into action and enhance their learning attitude?

\section{Materials and Methods}

To address the problems encountered in the Longevity Junior High School, four mathematics and science teachers began to implement a four-year action research program. The program's details are provided next.

\subsection{Research Framework}

This study adopted practical action research [37]. This approach starts with identifying a problem in an educational setting, and its quality depends on whether the research: (1) took action? (2) solved the problem or added to our knowledge? (3) had repetitive cycles? (4) developed a comprehensive understanding? (5) produced a fundamental change? (6) adopted an understanding of the ethical framework? (7) included diverse data collection methods; (8) constructed pre-understanding of the environment and situation, and (9) responded in real-time [38]. The researchers examined from time to time if the implementation process of the study met the above evaluation criteria.

The Makers Club was conducted over four years and four action research cycles ( $\mathrm{Au}-$ gust 2015 to July 2019). First, schoolteachers made a practical judgment on environmental issues and four teachers in this study decided to participate in a professional development program organized by a nearby university to enhance teachers' professional development in line with the energy education project promoted by the Ministry of Education [39]. They established a Makers Club and designed the engineering-centered PjBL on sustainable energy curriculum to guide club students in their project-based work, incorporating global warming and energy sustainability issues into the curriculum (August 2015). The study was conducted in one unit per year for four years (Figure 1). Each year, the four club teachers reflected on the development of students' creativity and engineering technical skills as they designed the curriculum, asking themselves: Has the concept of environmental sustainability been translated into action? Have attitudes toward learning improved? Then the curriculum was revised and adjusted per the results of these questions, and an action plan for improvement was developed for the following year.

Each year, the engineering-centered PjBL was divided into five phases-preparation, implementation, presentation, competition, and feedback [12] — and was implemented for 11 months (2015 Sep 2016 Jul, 2016 Sep 2017 Jul, 2017 Sep 2018 Jul, and 2018 Sep 2019 Jul). At the end of each school year, the four club teachers identified the strengths and weaknesses of the problems encountered during the implementation process, collected data on students' observations and interviews on learning problems, reflected on the impact of engineering-centered PjBL on teachers, students, and school, and prepared an action plan for improvement in the following year (2015-2019 each Aug). 


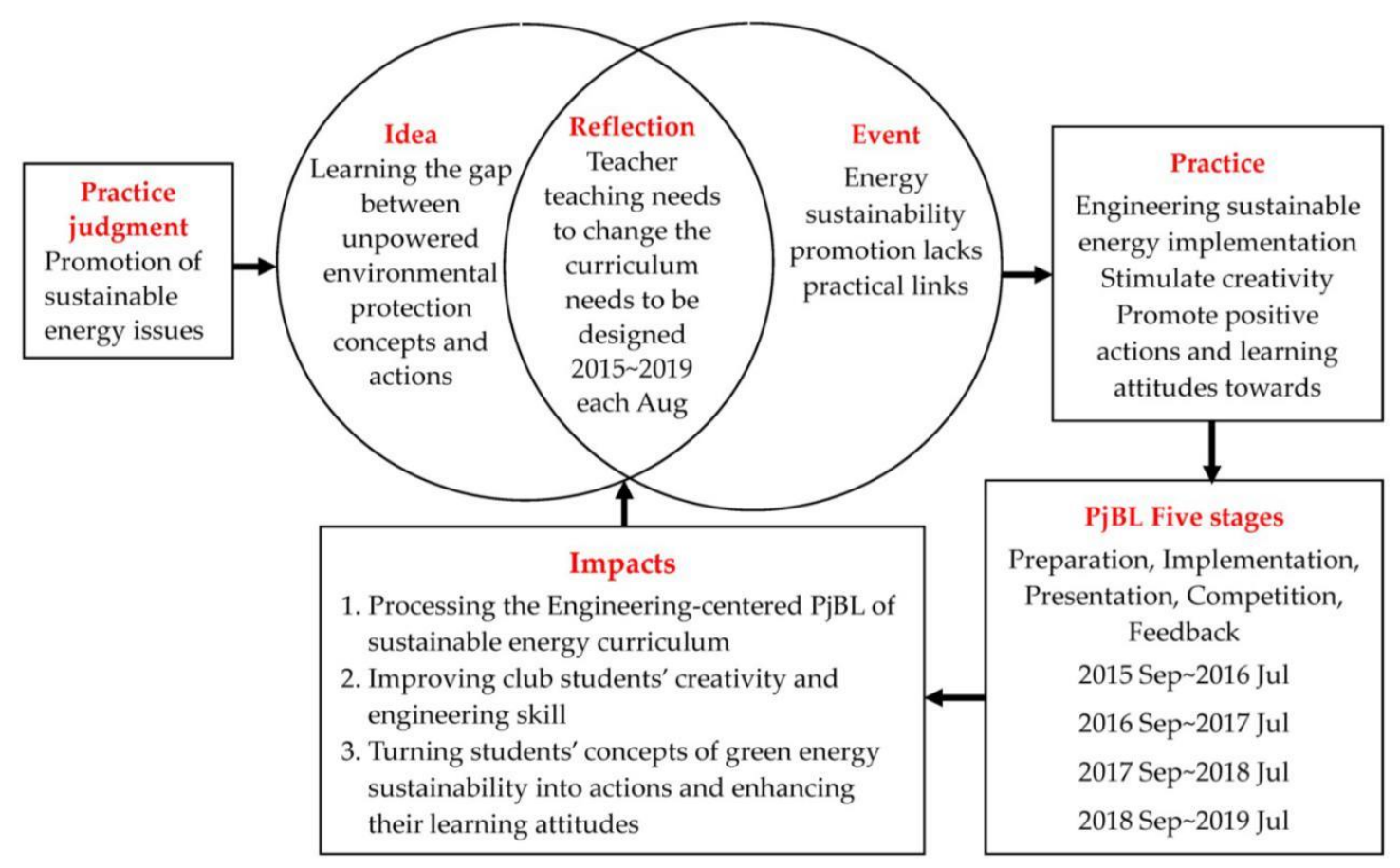

Figure 1. Research framework of the practical action research revised from [37].

\subsection{Participants}

Longevity Junior High School is a small, rural school of about 150 students with a high percentage of disadvantaged students in Eastern Taiwan. The school has worked with the Tzu Chi Foundation for many years to promote the concept of energy sustainability and love for the earth. Each year, the seventh- and eighth-grade teachers recommend appropriate students from among those who volunteer to participate in the Markers Club, then the club teachers select 15 students to participate in the Markers Club's projects on sustainable energy. These students were divided into five groups (A to E), with three students in each group. Although the students were behind their peers in academic achievement, they all demonstrated problem-solving skills and an inclination to enjoy hands-on engineering work. Students chose their projects based on their interests. Not all groups focused on green energy generation, but each group's project had to incorporate energy sustainability or environmental issues. There were three research questions (RQ) in this study. The observations on creativity and engineering technical skills (RQ2) were based on the 15 students who participated in the Makers Club each year. The participants in RQ3 included the 15 students who participated in the club as well as other students from across the campus.

Four mathematics and science teachers $\left(\mathrm{T}_{1}-\mathrm{T}_{4}\right)$ were involved in the planning and teaching of this club; two were chemistry teachers $\left(\mathrm{T}_{2}\right.$ and $\left.\mathrm{T}_{3}\right)$, one was a physics teacher $\left(\mathrm{T}_{4}\right)$, and the first author of this paper $\left(\mathrm{T}_{1}\right)$. The first author of this study was a certificated teacher in electrical and electronic engineering, mathematics, information technology, and a participating observer. He was the only teacher with an engineering background. One of the chemistry teachers was the principal of Longevity Junior High School $\left(\mathrm{T}_{2}\right)$. All participants were informed about the research in keeping with research ethics practices in Taiwan.

\subsection{Data Collection}

Data on students' creativity development and engineering technical skills were recorded by students in their learning notes $(\mathrm{N})$, teachers' instructional observations $(\mathrm{O})$, teachers' and students' feedback on project work exhibited on campus (F), and external competition judges' feedback on the overall composition and functionality of the project 
(F). The results of the project's participation in the Energy Sustainability-related invention competition were also considered as objective supporting evidence.

The evaluations of environmentally sustainable practices were based on students' learning notes $(\mathrm{N})$, students' feedback after competitions $(\mathrm{F})$, and newspapers and media reports. The assessments of learning attitudes were based on students' learning notes $(\mathrm{N})$, interviews (I), and peer observations $(\mathrm{O})$ and interviews (I) on academic performance, peer interaction, and impact on the class after the students returned to their original class. The club teachers and students document a photo album of sustainable energy practices together every year (A). Students' scores of the national comprehensive assessment program (CAP) for junior high school students each year and school enrollment rates were considered indirect but objective evidence to support school-wide changes in student learning attitudes.

\subsection{Data Analysis}

This study used multiple data sources for triangulation. Three codes were used to code all the data. The first code was the informant, which includes teachers, students, judges, and peers. The second code was the data source, including feedback, interviews, observations, reflections, album, and notes. The third code was the academic year. Two authors examined and coded the data, and used constant comparative method to classify all the data into constructs of interest to researchers. Discrepancies in classification were discussed until agreement was reached. Table 1 provides the coding table for qualitative data, for example,

- $T_{1}-R_{1}-Y_{5}$, denotes Teacher 1's reflection for the first time in the 2015 school year.

- $\mathrm{S}_{\mathrm{A} 1}-\mathrm{O}_{2}-\mathrm{Y}_{6}$, represents the classroom observation record of Student 1 in Group A for the 2nd time in the 2016 school year.

Table 1. Coding Table for Qualitative Data

\begin{tabular}{|c|c|c|c|c|c|c|c|c|c|c|c|}
\hline $\begin{array}{l}\text { Explana- } \\
\text { tion }\end{array}$ & & $\begin{array}{l}\text { Code } \\
\text { inforr }\end{array}$ & & & & & $\begin{array}{r}\text { Cod } \\
\text { data } \mathrm{s}\end{array}$ & $\begin{array}{l}\text { 2: } \\
\text { irce }\end{array}$ & & & $\begin{array}{c}\text { Code 3: } \\
\text { year }\end{array}$ \\
\hline Code & $\mathrm{T}$ & $S$ & $\mathrm{~J}$ & $\mathrm{P}$ & $F$ & I & $\mathrm{O}$ & $\mathrm{N}$ & $\mathrm{R}$ & A & $\mathrm{Y}$ \\
\hline Meaning & Teacher & Student & Judge & Peer & Feedback & Interview & $\begin{array}{l}\text { Obser- } \\
\text { vation }\end{array}$ & Note & Reflection & Album & $\begin{array}{l}2015 \\
2018\end{array}$ \\
\hline Numbering & $1 \sim 4$ & $\begin{array}{l}\mathrm{A}_{1-3 \sim} \\
\mathrm{E}_{1-3}\end{array}$ & $\begin{array}{l}\mathrm{A}_{1-3 \sim} \\
\mathrm{E}_{1-3}\end{array}$ & $1 \sim 20$ & $1 \sim 4$ & $1 \sim 3$ & $1 \sim 6$ & $1 \sim 4$ & $1 \sim 4$ & $1 \sim 15$ & $5 \sim 8$ \\
\hline
\end{tabular}

\section{Curriculum Design}

The club teachers designed a diverse and inspiring engineering-centered PjBL teaching model based on the idea of sustainable energy through engineering technology to enhance students' creativity and problem-solving engineering technical skills. The curriculum was designed in a five-phase model: Preparation, Implementation, Presentation, Competition, and Feedback. In the Preparation and Implementation phases, teachers trained students to learn the sustainable energy knowledge and engineering technical skills required for the project. The time required is flexibly adjusted according to students' learning status. During the Presentation phase, teachers arranged public displays for students' work of energy sustainability and environmentally conscious in the school, encouraged students to view or manipulate these works during class breaks, and encouraged peer and self-evaluation.

The Competition and Feedback phases were used to revise the project work after selfevaluation and peer review for the off-campus competition. The feedback from the 
external judges was more helpful for students' reflection and internalization into the motivation of learning. The club teachers used energy sustainability as the curriculum content, introducing various forms of power generation (e.g., thermal, nuclear, hydroelectric, wind, solar, hydrogen fuel cell, geothermal, tidal, and ocean currents) to inspire students' creative ideas and thinking about energy sustainability.

The average teaching time was two lunch breaks (about 40 minutes) and one class (45 minutes) per week, with additional sessions during winter and summer vacations. It was about 100 minutes per week in total. The five stages of PjBL implementation for each school year and the time allotted for teachers to participate in various professional development workshops in August each year and to reflect and revise the curriculum for the next school year are shown in Table 2 .

Table 2. Five-phase Implementation Steps and Teacher Reflection Time Allocation

\begin{tabular}{ccccccc}
\hline School year & Preparation & Implementation & Presentation & Competition & Feedback & Reflection \\
\hline 2015 & 16 weeks & 25 weeks & 2 weeks & 2 weeks & 3 weeks & 4 weeks \\
\hline 2016 & 16 weeks & 25 weeks & 2 weeks & 2 weeks & 3 weeks & 4 weeks \\
\hline 2017 & 18 weeks & 23 weeks & 2 weeks & 2 weeks & 3 weeks & 4 weeks \\
\hline 2018 & 20 weeks & 21 weeks & 2 weeks & 2 weeks & 3 weeks & 4 weeks \\
\hline
\end{tabular}

\section{Results}

The main reason for the lagging academic achievement of rural students is that they are not interested in the curriculum content. The lack of teachers, high mobility, and lack of professional guidance for students' specialties will not motivate students to learn over time. The club teachers followed the PjBL model suggested by Han [40] and Krajcik and Czerniak [13], which provided students with (a) various tasks to solve real-life problems, (b) scientific and engineering practices and scaffolding to simplify complex ideas, and (c) created work to solve problems. After incorporating the energy sustainability project into their hands-on work, students' collaborative learning continued to show results in the development of creativity, engineering technical skills, sustainable energy actions, and learning attitudes. The research results are presented next.

\subsection{The Process of Engineering-centered PjBL of Sustainable Energy}

With the professional development of the club teachers and the legacy of the club seniors, each year the PjBL curriculum was designed to provide the latest technology. The club students continued to refine their engineering technical skills, identify problems in simulations and hands-on work, and generate ideas to overcome them. The curriculum process that led students to practice and demonstrate sustainable energy over the years is described below.

\subsubsection{Inquiry of ceiling fan and ventilation ball generator (August 2015 July 2016)}

In the first year, the idea of renovating an old ceiling fan generator in the classroom came from three students who helped the school to replace the abandoned ceiling fan during the summer vacation. The principal $\left(\mathrm{T}_{2}\right)$ proposed the idea of dismantling the coil assembly to use for electricity generation. As a result of this suggestion, the principal encouraged the researcher $\left(\mathrm{T}_{1}\right)$ and the mathematics and science teachers to establish a Makers Club so that these three students and others students could continue to explore in the club environment.

\subsubsection{Preparation phase (16 weeks)}

The club teachers and students collected all the abandoned ceiling fans in the school for the club teaching. The primary teaching content in the Preparation phase was to disassemble the ceiling fan, train the students to know the structure of a ceiling fan, sort the 
disassembled parts, and develop good work habits. The principles of various types of generators were also explained in this phase. The disassembled ceiling fan components and wiring are shown in Figure 2.
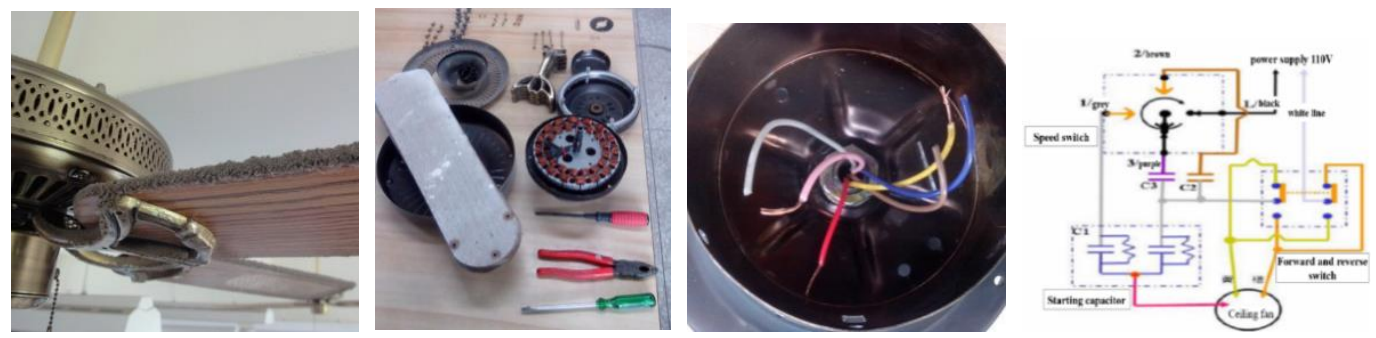

Figure 2. Students dismantle abandoned ceiling fans and conduct experiments $\left(\mathrm{S}_{\mathrm{A}}-\mathrm{A}_{5}-\mathrm{Y}_{5}\right)$.

\subsubsection{Implementation phase ( 25 weeks)}

Preliminary investigations had the students applying strong magnets and rotating the ceiling fan turntable to get power output; because the voltage waveforms were irregular, the data of the voltage waveforms tested by the students were not accurate. Therefore, the club teacher assigned each group a project task and encouraged the students to solve the problem of messy waveforms and find the method that maximized power generation (Figure 3).
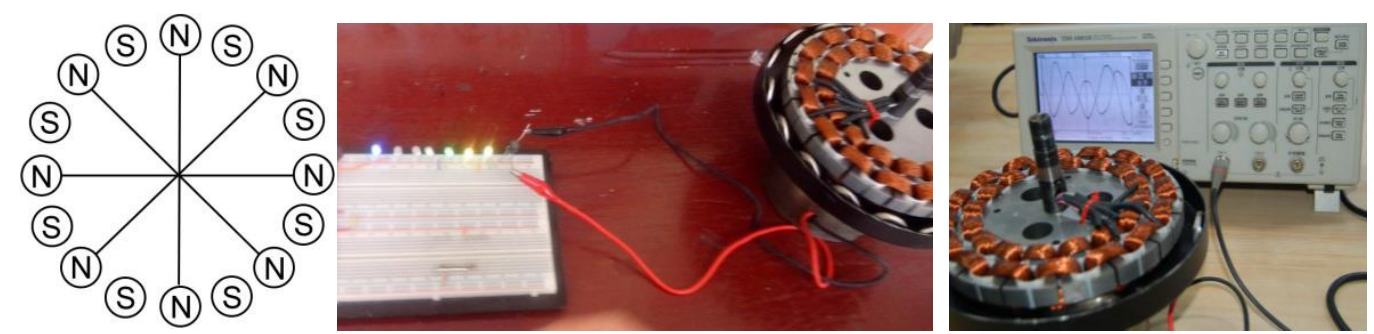

Figure 3. Project task: Solving the problem of voltage waveform irregularities and finding a way to maximize power generation $\left(\mathrm{S}_{\mathrm{B}}-\mathrm{A}_{4}-\mathrm{Y}_{5}\right)$.

The students worked in groups to experiment with wind power generation by making fan blades and combining them with ceiling fans using thick cardboard and plastic building blocks. After several months of brainstorming, the students in Group C completed the integration of the ventilation ball and the ceiling fan coil assembly into a working wind-power generation device (Figure 4, Figure 5).
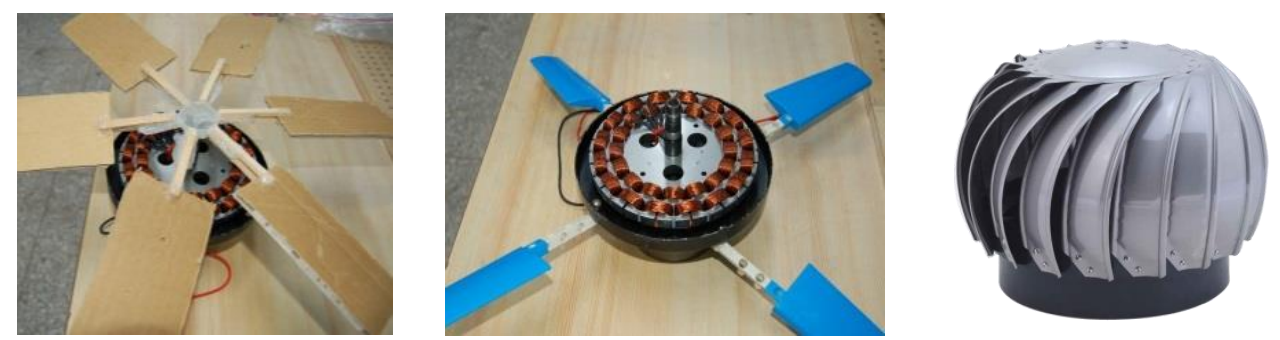

Figure 4. Each group made different blades, and group $C$ found a way to make the wind ventilator have stable power generation $\left(\mathrm{S}_{\mathrm{A}}-\mathrm{A}_{8}-\mathrm{Y}_{5}\right)$. 

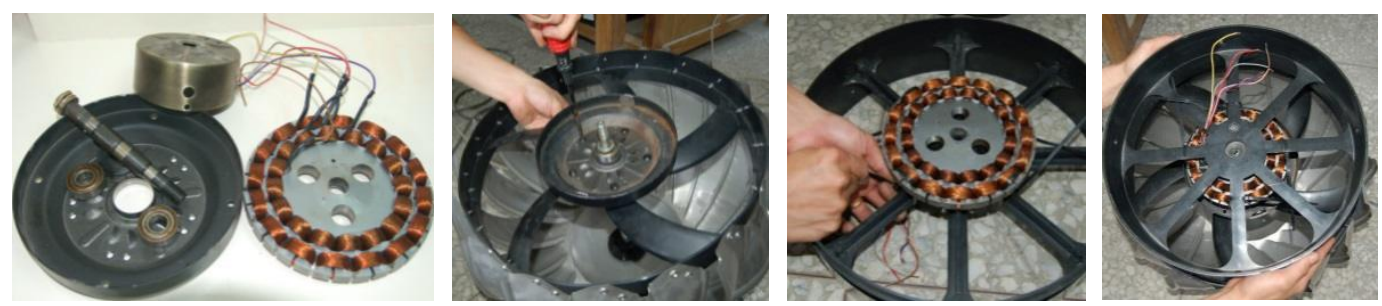

Figure 5. With collaborative learning and appreciation of the group's strengths, the students created the perfect ventilation ball generator ( $\left.\mathrm{S}_{\mathrm{c}}-\mathrm{A}_{9}-\mathrm{Y}_{5}\right)$.

\subsubsection{Presentation phase (2 weeks)}

The club teachers and the school administration arranged for each group to display their project work in the school and encouraged all students to visit or manipulate. The students illustrated the principle of wind power generation based on Lenz's law, which states that when the magnetic field changes, the coil generates an induced current to resist the change in the magnetic field.

Taking Group C as an example (Figure 6), students used the assembled wind turbine to show the voltage waveform data generated by the rotation of the wind ventilator under different magnet arrangement conditions (Table 3). The results showed the peak-to-peak voltage value with $8 \mathrm{~N}$ poles and $8 \mathrm{~S}$ poles was as high as $54.0 \mathrm{~V}$.
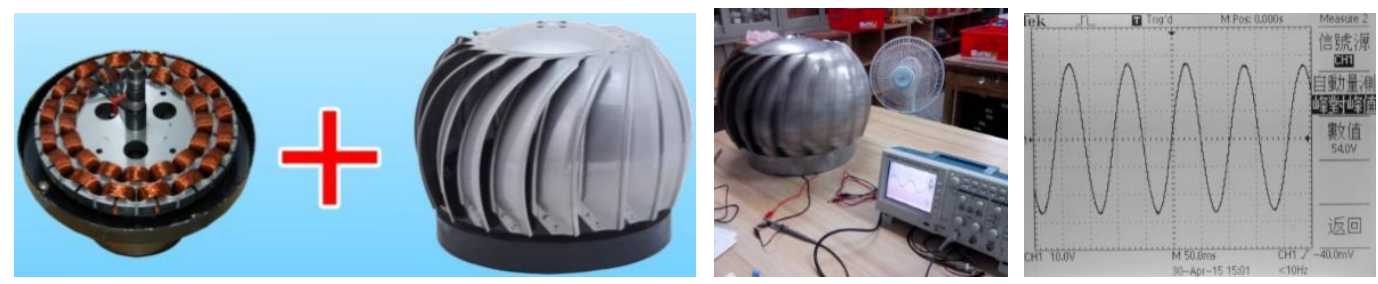

Figure 6. Students were required to explain the power generation principle, experimental process, and research results during the Presentation phase (Sc-A11-Y5).

Table 3. Waveforms and Peak-to-peak Voltages Generated by Different Number of Magnets (Sc3$\left.\mathrm{N}_{6}-\mathrm{Y}_{5}\right)$

\begin{tabular}{ccccl}
\hline Experiment No. & Number of magnets & Arrangement & VP-P & Waveform description \\
\hline 1 & 1 N pole facing the coil & None & $4.3 \mathrm{~V}$ & Complete sine wave \\
\hline 2 & 2 N poles facing the coil & Isometric & $7.6 \mathrm{~V}$ & Complete sine wave \\
\hline 3 & 4 N poles facing the coil & Isometric & $13.3 \mathrm{~V}$ & Complete sine wave \\
\hline 4 & 8 N poles facing the coil & Isometric & $20.6 \mathrm{~V}$ & Complete sine wave \\
\hline 5 & 16 Npoles facing the coil & Isometric & $1 \sim 1.3 \mathrm{~V}$ & Waveform is deformed \\
\hline 6 & $\begin{array}{r}8 \mathrm{~N} \text { poles and 8 S poles } \\
\text { facing the coil }\end{array}$ & Isometric & $54.0 \mathrm{~V}$ & Complete sine wave
\end{tabular}

${ }^{1}$ The number of magnets other than the above cannot produce a complete sine wave waveform.

\subsubsection{Competition phase (2 weeks)}

The Competition phase lasted for two weeks, and the club teachers conducted a selfassessment and peer-assessment before the competition for each group. All groups were asked to point out the improvements of other groups' works to challenge themselves and improve their current state to best prepare for the day of the competition (Figure 7). The researcher also invited students from the original class to assist in the evaluation to create 
a friendly atmosphere toward the Makers Club and recognize the meaning and value of energy sustainability.
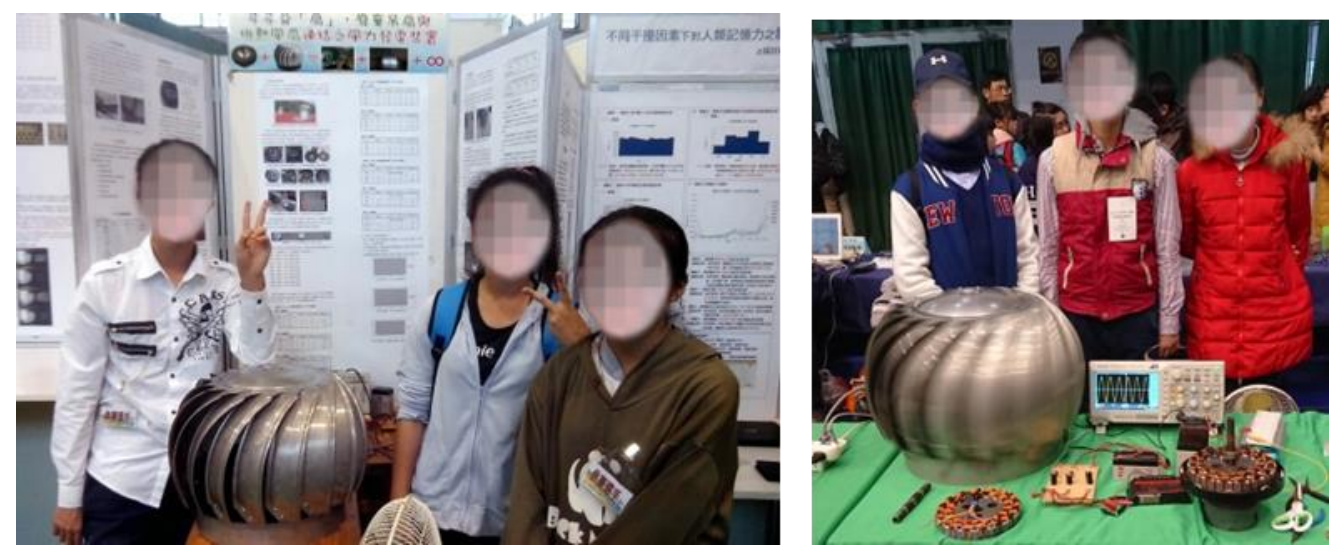

Figure 7. Students need to challenge themselves and break out of their current state in order to achieve good results in the Competition phase ( $\left.\mathrm{S}_{c}-\mathrm{A}_{12}-\mathrm{Y}_{5}\right)$.

\subsubsection{Feedback phase (3 weeks)}

The Feedback phase allowed the club teachers to assist students in making corrections to their work based on feedback from judges and expert advice, and then enhanced their engineering and practical skills. During this phase, students were guided to practice flexible thinking, develop the personality traits of not being afraid of failure and criticism, and take risks and challenge themselves in order to stimulate more creativity and original thinking (Figure 8). The club teachers paid special attention to the suggestions and ideas assessed by the club students' original classmates. The goal was to provide a sense of participation for the entire class and to create a culture of sustainable energy learning culture for the entire school.
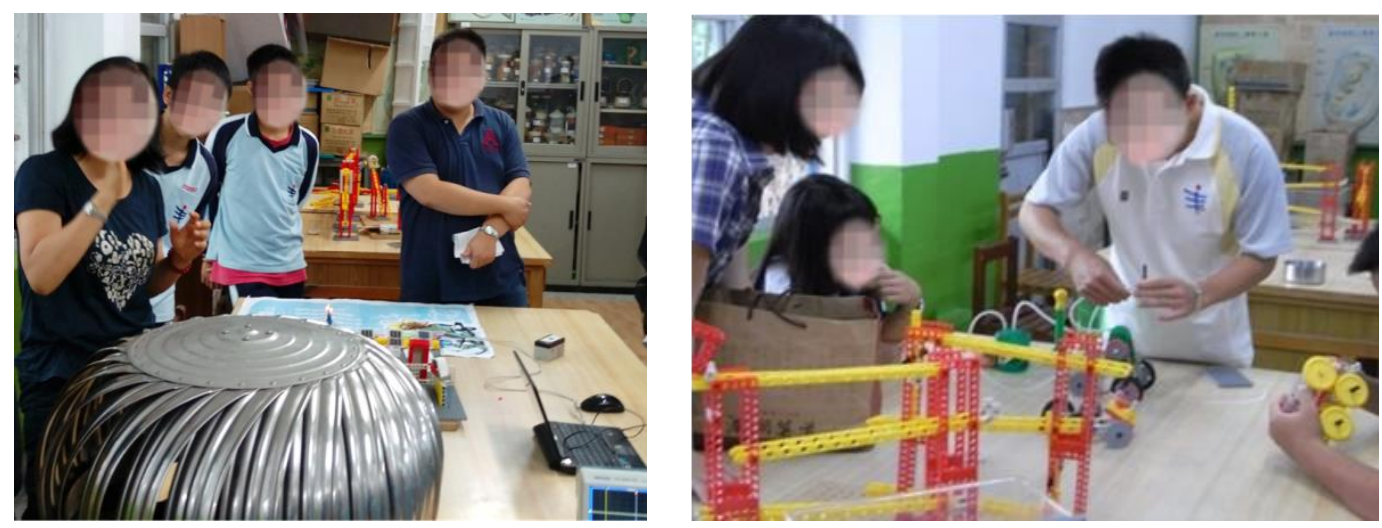

Figure 8. Club teachers assisted students in optimizing and correcting the functionality of their work based on the suggestions provided by the judges and classmates ( $\left.\mathrm{S}_{\mathrm{c}}-\mathrm{A}_{15}-\mathrm{Y}_{5}\right)$.

\subsubsection{Reflection and revision (4 weeks)}

In August, teachers participated in the professional development curriculum and gathered feedback from teachers and students to reflect and plan the curriculum for the next year. The following is a summary of the reflections and revisions made by the club teachers.

1. Creativity and engineering technical skills

- Only one theme of ceiling fan generator applications was monotonous. Arduino programming and automatic control courses could be added. During the next year, in line with the Ministry of Education's solar power promotion program, the club 
teachers decided to provide solar power generation options based on the existing wind power generation.

- The lack of space in the classroom affected the project presentations, which interfered with each other. It was suggested that the school open two classrooms for students to work on their projects and use them as a regular display space.

2. Sustainable energy practices and learning attitude

- Students have unlimited creativity and potential. The ventilation ball generator was very successful project work, and its performance was even better than what university students have done. The club teachers considered providing students with diverse aspects of green energy creation courses and encouraged them to participate in the competition with their developed green energy lesson plans to promote and deepen green energy engineering education continuously.

- The presentation of the project works was very effective. The design of the presentation made a good connection between concepts and practices. All the school students provided good feedback on the concepts and ideas of green energy, so it was appropriate to continue to promote it.

- The students' performance in the club demonstrated the creativity and practical abilities of these rural area students, thus boosting the self-confidence of other students in the school. This club curriculum should be developed continuously and become a unique feature of the school in the hope that it will influence the learning attitude of all students in the school.

3. Others

- The funding for rural schools was insufficient, and many materials had to be paid out of teachers' own pockets or borrowed from the vocational high schools. Next year, the club teachers decided to apply for more grants from the Ministry of Education's Energy Project or the Department of Education's Creativity Project.

- The club teachers encouraged each other to participate in the Arduino workshops organized by the neighboring universities to improve their professionalism and provide students with more profound and broader learning.

4.1.2 Parallel operation of ventilation ball generator and solar panel (August 2016 July 2017)

For the 2016 project, the school cooperated with the Ministry of Education's solar energy promotion plan, and the club teachers encouraged students to design various types of solar power devices. In order to increase the efficiency of the wind generator, some students wanted to use solar panels to generate electricity in parallel with the ventilation generator. The Competition and Feedback phases were similar to the first year, and the third and fourth years were the same as well.

\subsubsection{Preparation phase (16 weeks)}

Based on the reflections of the 2015 school year, the club teachers taught the students the Arduino knowledge and skills they acquired from participating in the maker workshops of the neighboring universities. The Arduino automation course was incorporated to enrich and diversify the club curriculum.

\subsubsection{Implementation phase ( 25 weeks)}

The club teachers encouraged students to use their ingenuity to expand the application of solar panels and increase power generation as this year's topic direction of sustainable energy. Some students wrote an Arduino program to design a solar panel that rotates 
with the Sun so that the surface of the solar panel rotates perpendicular to the Sun's rays over time to obtain the best electricity storage effect (Figure 9).
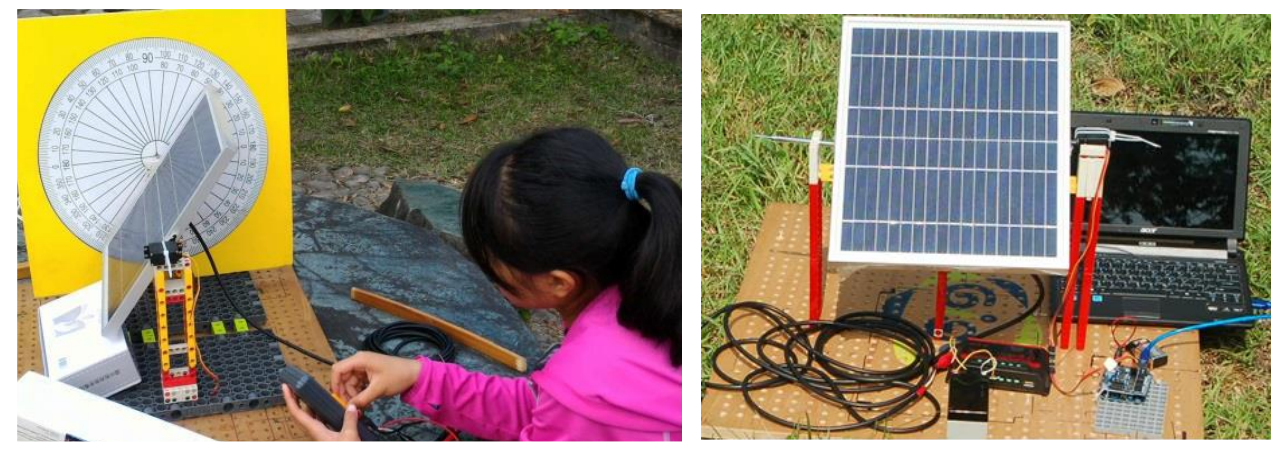

Figure 9. Students measured the angle between the solar panel and the sun, using Arduino control to obtain the best storage value $\left(\mathrm{S}_{\mathrm{A}}-\mathrm{A}_{3}-\mathrm{Y}_{6}\right)$.

\subsubsection{Presentation phase (2 weeks)}

The club teachers trained each group members' presentation skills then each club member was given the opportunity to make an oral presentation. At this phase, the club teachers tried to guide the Makers Club students to recognize the value of environmental sustainability by presenting their project to their peers in the original classroom and the teachers of the other subjects. Group A students, for example, drew posters showing the effect of a ventilation generator and a rotating solar panel connected in parallel to store electricity and explained the concept of their work (Figure 10).

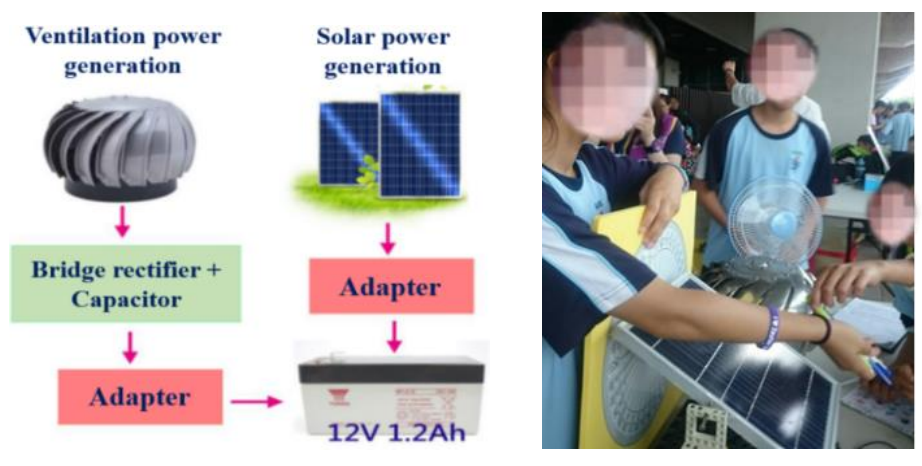

Figure 10. Flowchart and actual test of parallel power generation between ventilation generator and solar panel in the campus $\left(\mathrm{S}_{\mathrm{A}}-\mathrm{A}_{8}-\mathrm{Y}_{6}\right)$.

\subsubsection{Reflections and revision (4 weeks)}

The following are the reflections and revisions made by the club teachers.

1. Creativity and engineering technical skills

- The solar panels provided by the Ministry of Education were not powerful enough to conduct parallel experiments with wind power. This problem was solved by purchasing two solar panels with sufficient power. However, the groups that were not assigned high-powered solar panels used their creativity to design the projects on greenhouse energy and automatic clothes drying racks.

- The Arduino automation course allowed students in each group to cooperate and learn to support each other according to their expertise, which had a good effect, strengthened the project's quality, and suggested that the course design continue to increase Arduino's importance. 
- $\quad$ The parallel power generation device was more complicated for the students, but the students were earnest about learning and working together to complete the task. After this practical work, their engineering technical skills were greatly enhanced.

- $\quad$ Planning to teach and pass on the knowledge and engineering technical skills of sustainable energy to younger students through the mentorship of the Makers Club helped students get into the swing of things.

2. Sustainable energy practices and learning attitude.

- Arduino's programmable control was easily integrated into the energy sustainability issue, which helped them to put their ideas into practice.

- $\quad$ The design of wind and solar power in parallel took full advantage of the school's daytime sun light and nighttime land breeze environment to generate electricity 24 hours a day.

- The presentation at the school was well received, and the students solved their energy problems, providing a more profound practical experience of energy sustainability for the students who developed the idea and for the whole school.

- $\quad$ The Feedback and Competition phases have been successful. The principal arranged for a hydroelectric competition of the technical universities in the next year to enhance students' diverse learning experience about green and sustainable energy.

- $\quad$ Continuous arrangement of Tzu Chi NGO environmental protection station visits and beach cleaning activities enhanced students' awareness of the importance of environmental protection and stimulated the connection between ideas and practical thoughts.

- $\quad$ The wind and solar power projects were recommended to be displayed on campus for a long time to record the students' efforts to turn their ideas into actions and enhance the whole school's learning motivation to follow the model example.

- Club teachers will integrate the community's work into the general curriculum in order to inspire peer learning.

3. Others

- $\quad$ The work and inventions require many material costs, which was quite difficult for a rural school. Teachers need to continue applying for other Ministry of Education project support.

4.1.3 Installation of hydroelectric and ocean current power generators (August 2017 July 2018)

Under the guidance of the grade 9 seniors, the students of the Makers Club generated many creative ideas. Some students thought that there were too many disturbing factors for wind power generation and that without wind or varying wind speed, the power generation function would be affected. In addition, the technical universities conducted a hydropower competition near the school. Some students thought that there are many high mountains near the campus and the water flow from high mountains is fast, and the canals for irrigation are everywhere in the rural area.

\subsubsection{Preparation phase (18 weeks)}

In the 2017 school year, the club teachers used the hydroelectric competition proposed by the principal $\left(\mathrm{T}_{2}\right)$ as the central focus but continued to encourage students to think about multifaceted sustainable energy issues. Each group used different materials (e.g., wood, plastic, acrylic, or iron) to create a hydroelectric generator. After the 
generators were in regular operation, a simple test was conducted using the school's rainwater tanks to simulate water flow. Group D, for example, used a discarded flagpole base as the bottom mechanism. Different blade patterns were designed, and two layers of coils from the original ceiling fan generator were added to increase the power generation capacity, and the design was continuously revised (Figure 11).
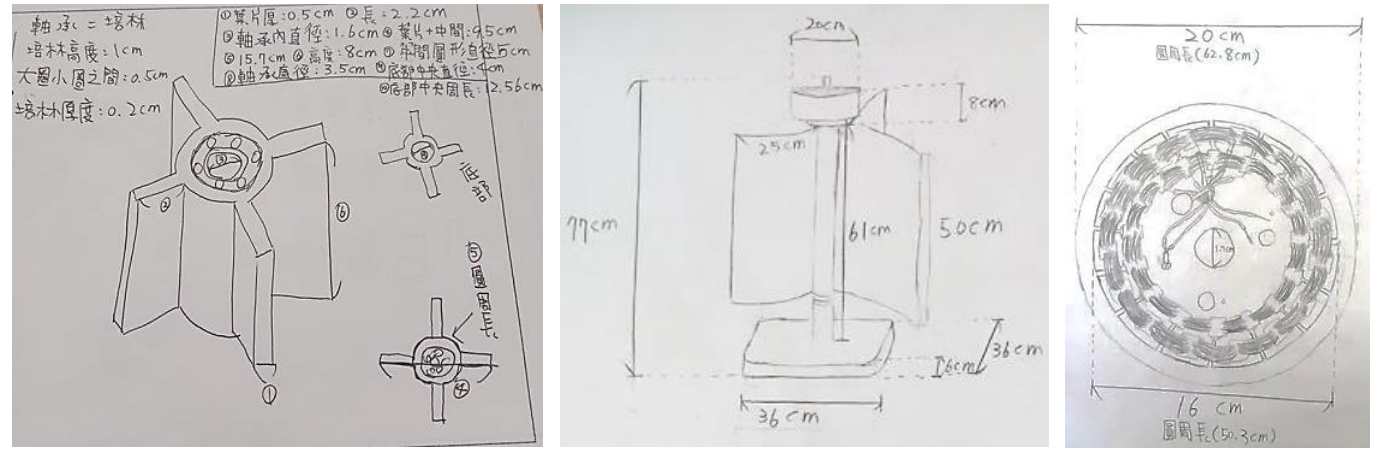

Figure 11. Students used the coil assembly of the ceiling fan to modify the 4 blades into 3 blades $\left(\mathrm{S}_{\mathrm{D} 1}-\mathrm{N}_{2}-\mathrm{Y}_{7}\right)$.

\subsubsection{Implementation phase (23 weeks)}

Each group tried to create a hydroelectric generator design with the most robust structure and the best number of blades. Since the competition was held in an actual water canal, the club teachers took the students to a canal near the school to conduct a practical test to simulate hydroelectric generators. For example, the students in Group D designed a vertical structure of the generator that was unlike the horizontal structure of Group C, which used a discarded wheelchair as the rotor (Figure 12). The students also measured the water current velocity at about $1.2 \mathrm{~m} / \mathrm{s}$, which is comparable to that of the Kuroshio tide, so the students in Group D thought that the hydroelectric generator they developed might apply to "ocean current power generation."

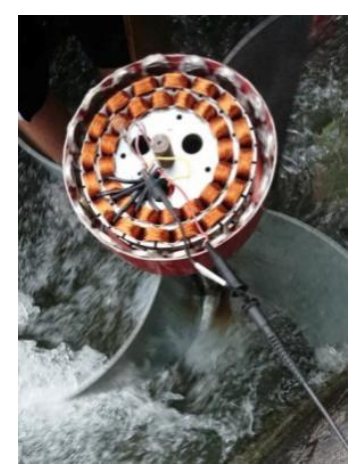

(a)

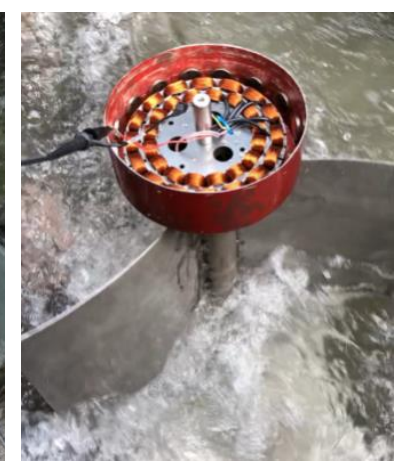

(b)

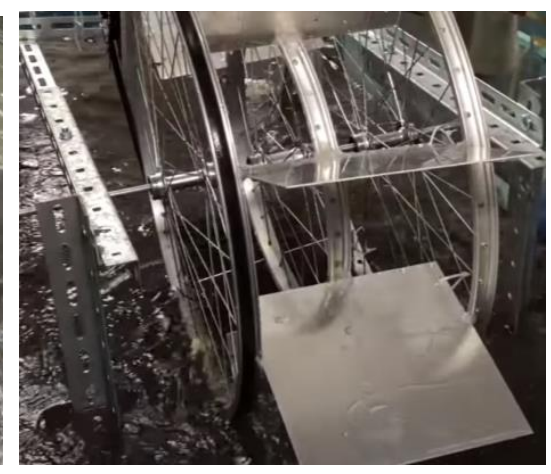

(c)

Figure 12. (a) \& (b) Group D students designed vertical axis generator and tested them with different number of blades than (c) the horizontal structure of Group C students.

\subsubsection{Reflections and revisions (4 weeks)}

1. Creativity and engineering technical skills

- The experiment of putting the hydroelectric generators into the canal created problems (e.g., the flow of the rainwater tanks simulation was too small, the non-iron works could not be used after being laid in the canal). Students experienced the difference between wind and water power. New problems triggered creativity and required new engineering techniques to solve them. 
- $\quad$ Some unsuccessful groups changed their green energy topic to Arduino control.

- $\quad$ Some projects were very creative. Group B students investigated the rural roads and calculated the amount of emissions and energy consumption when there are no cars on the rural roads but cars need to stop for red lights (Figure 13). The project is not only creative but also gives the students and teachers first-hand experience.

- $\quad$ Because of the high kinetic energy of water, the hydroelectric generator can drive multilayer coils. Students completed two-layer coils to generate electricity with good results and sustainable development of multilayer coils with expanded hydroelectric generators.

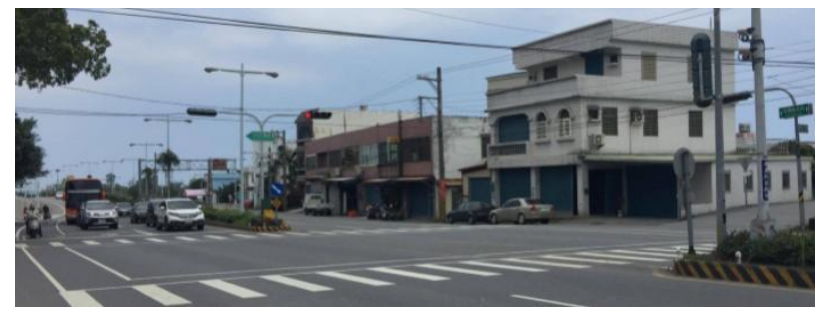

(a)

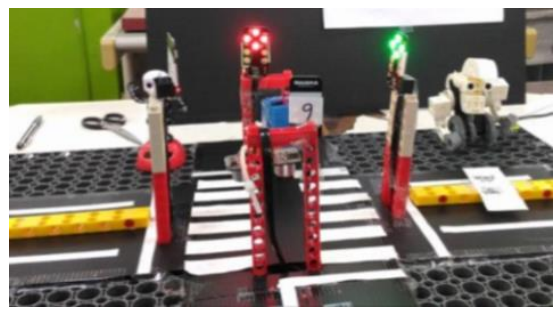

(b)

Figure 13. (a) No cars on the rural roads, but cars need to stop for red lights on the main road. (b) Group $B$ designed the intelligent traffic light to solve this problem $\left(S_{B}-A_{2}-Y_{7} \& S_{B}-A_{10}-Y_{7}\right)$.

2. Sustainable energy practices and learning attitude

- The hydroelectric generators were displayed in the concourse, and the feedback from the students and teachers was positive.

- Although only one group completed the hydroelectric device, the unsuccessful works gave the entire school a sense of how difficult it is to generate sustainable energy.

- $\quad$ The green energy project was a multifaceted project that provided a comprehensive learning experience for all students and teachers.

- We proposed displaying the best green energy projects on campus as a record of the students' efforts to turn ideas into action and enhance school students' learning attitude through the influence of the environment.

3. Others

- $\quad$ The education authorities promoted 3D printing technology. The club teachers decided to use their professional development time to explore the use of this new technology.

4.1 4 3D Printing expandable wind power generation (August 2018 July 2019)

For the 2018 project, as the education authority allocated six 3D printers to rural schools, the club teachers arranged 3D drawing and printing as the preparation focus for this year's project after attending the education training.

\subsubsection{Preparation phase (20 weeks)}

According to the students' feedback, they believed that the wind turbine is too heavy and bulky, so the project direction this year was to use 123D drawing software to draw the main body, base, and blades of the wind turbine and print the output of a lightweight 3D wind turbine. The goal was to enhance the 3D drawing ability of the students and to use $3 \mathrm{D}$ printing to solve real-life problems, which required the preparation time be extended to 20 weeks. 


\subsubsection{Implementation phase ( 21 weeks)}

The coil assembly of the generator used by the students was still the coil of a discarded ceiling fan, and veneer calipers precisely measured the disassembled coil assembly of the ceiling fan and the magnet before drawing and printing (Figure 14). For example, the power generated by Group A's 3D wind turbine is no less than that of the previous expanded multifunctional generator, with one layer of coil generating about $30 \mathrm{~V}_{\mathrm{P}-\mathrm{P}}$ and two layers of coil generating up to 60 VP-P. However, since the printing time of wind turbines was too long and prone to malfunction, some groups integrated Arduino control with the drawing capability to design variable products for environmental protection.
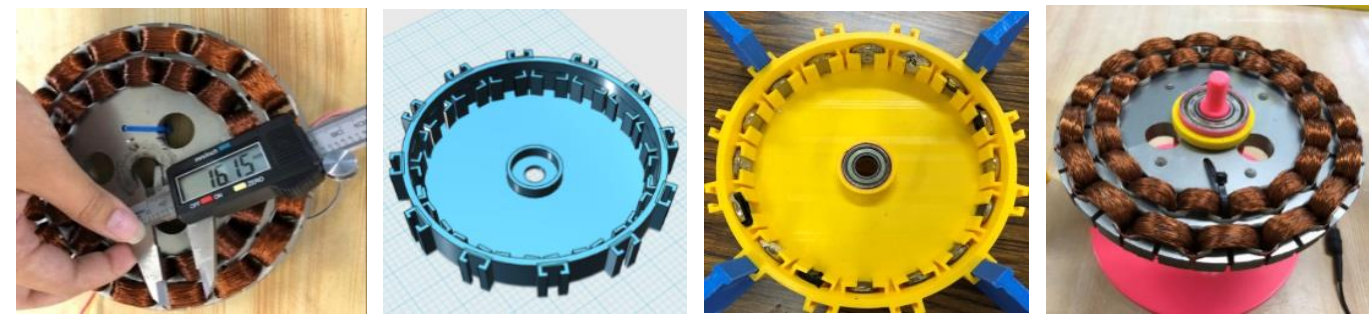

Figure 14. Students used 3D drawings to print wind turbines, completed the assembly, and conducted wind power charging tests $\left(\mathrm{S}_{\mathrm{A}}-\mathrm{A}_{6}-\mathrm{Y}_{8}\right)$.

\subsubsection{Presentation Phase (2 weeks)}

Due to the promotion of 3D printing this school year, the work on energy sustainability during the Presentation phase was more substantial. In addition to 3D printing of wind turbines, there was work to conserve the marine environment of ocean sunfish (i.e., a characteristic fish species in the marine area near the school), greenhouses, rainwater collection tanks, automatic sprinkler systems, and other topics. Students collaborated on tasks such as hands-on explanations, role-playing, and data analysis to promote schoolwide recognition of the value of environmental sustainability (Figure 15).
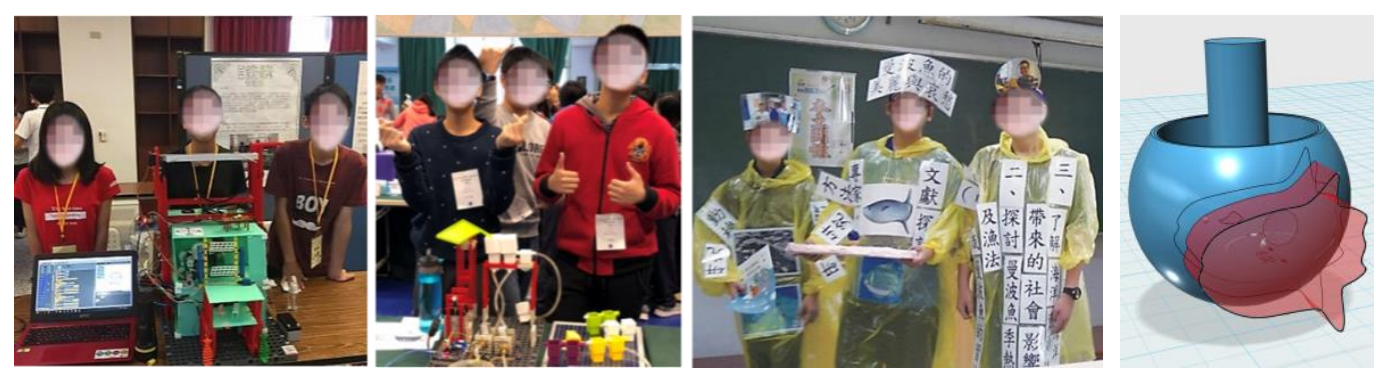

Figure 15. Students presented their work in the campus with a variety of energy sustainability topics $\left(\mathrm{S}_{B C D}-\mathrm{A}_{6}-\mathrm{Y}_{8}\right)$.

\subsubsection{Reflections and revisions}

1. Creativity and engineering technical skills

- This year, there were multifaceted topics that required students to learn more ideas and see different works. We saw that the students' creativity was unlimited, and the function and structure of their works were completed.

- The diversified theme of sustainable energy can stimulate more ideas and creativity; we continue to promote a multifaceted curriculum, suggesting the integration of 17 Sustainable Development Goals [41] as the main direction of creative ideas.

2. Sustainable energy practices and learning attitude

- This year's works were rich; including a 3D wind turbine, a 3D printed ocean sunfish gyroscope, and a 3D printed rainwater tank's automatic water sprinkler system. It 
was suggested that a multifaceted, open-ended approach to curriculum planning would allow for a more diverse approach to energy sustainability.

- There is need for a dedicated space to display students' green energy projects. Students have given excellent feedback after visiting and operating student projects. It was worthwhile to continue to invest in planning a dedicated classroom for displaying students' sustainable energy designs.

- The school had developed a club-based curriculum as a unique school feature, creating an educational environment where ideas were turned into action and helping low-achieving students enhance their learning motivation.

- The theme of the Makers Club was not limited, so students were free to develop their ideas, and non-club students were encouraged to contribute ideas.

- We planned to use the morning assembly time to present the project and encourage students to demonstrate it on stage next school year. It would strengthen the students' concept of environmental sustainability and serve as a model for the whole school.

3. Others

- The 3D printing wind turbine is lightweight, portable and can be promoted to other schools.

4.2 How does engineering-centered PjBL impact the Makers Club students' creativity and engineering technical skills?

The club teachers adopted a student-centered teaching method in PjBL to provide scaffolding for the Makers Club learning. The content taught was all the latest engineering technology techniques that the teachers had just acquired from their university professional development workshops; they had new knowledge and skills to construct new practical products with students. The teachers helped students to prepare suitable environments to test their ideas, such as Arduino control, rainwater tanks, water canals, and $3 \mathrm{D}$ printing, to stimulate students' creativity.

\subsubsection{Preparation and Implementation phases}

Teachers transformed the new technologies acquired into the curriculum, and the system of experience transfer from senior students increases the students' understanding, independent learning motivation and further strengthens creativity and engineering technical skills.

During the Preparation phase, the club teachers transformed the new techniques learned in their professional development to design the course content. Students were encouraged to participate in a self-directed research group, which enhanced their learning interests, knowledge understanding, and demonstrated their self-confidence. The Implementation phase was conducted after each group identifies their topic. The teacher provided materials and engineering techniques to guide the club students to enhance their engineering technical skills and abilities through continuous student mentorship.

- $\quad \mathrm{S}_{33}-\mathrm{I}_{1}-\mathrm{Y}_{5}$ : The making of the generator gave me a sense of accomplishment and gave me a deeper understanding of how electricity is generated. We disassembled the ceiling fan and put on the strong magnet that the teacher brought back from the university to test it. Really generate electricity, it was great. (20151018 in Makers Classroom)

- $\quad \mathrm{S}_{\mathrm{A} 2-}-\mathrm{I}_{1}-\mathrm{Y}_{6}$ : Aduino is very useful, my seniors taught us many practical skills and applied to many daily problems, I think I gained a lot. I used S4A to write a program to calculate the angle of the sun's rotation every minute, so that the power generation of the solar panel can be increased. (20170308 in Makers Classroom) 
- $\mathrm{S}_{\mathrm{C} 1}-\mathrm{I}_{1}-\mathrm{Y}_{8}$ : Last year, my seniors' hydroelectric generator participated in the national science fair competition, but it was too bulky to be shown in the exhibition. So we wanted to make a lightweight generator that we could carry around with us. After discussing the principles and engineering techniques with seniors, overcome the problem of mechanism assembly, learned 3D drawing, and then printed it out (Figure 16); it was great! (1081117 in Makers Classroom)
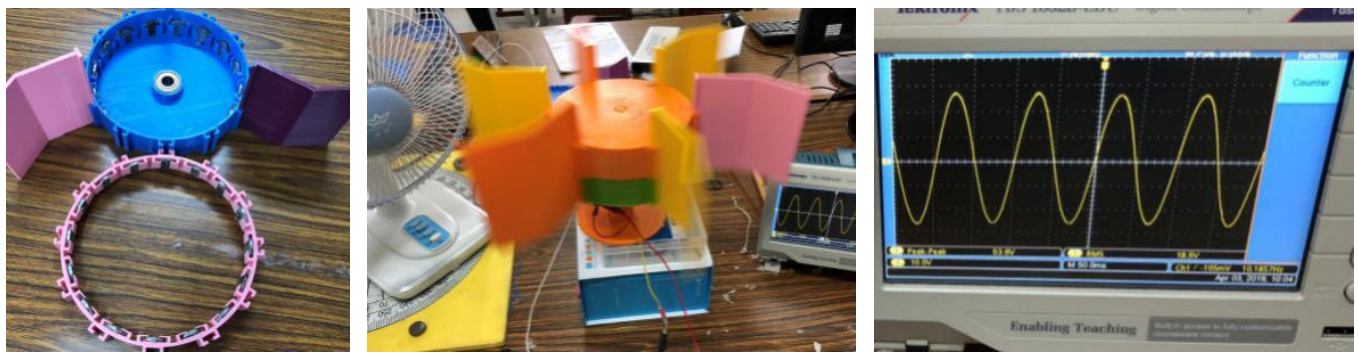

Figure 16. Students used 3D printing to design a lightweight wind turbine with multilayer coils and shared their drawings and practices with others $\left(\mathrm{S}_{\mathrm{A}}-\mathrm{A}_{11}-\mathrm{Y}_{8}\right)$.

\subsubsection{Presentation, Competition and Feedback phases}

Presentation and competition enhanced the development of students' creativity, while multiple feedbacks were internalized as improvement nutrients. Once the Markers Club students completed their project work and presented it at school to receive feedback from the entire school, the club teachers encouraged the completed work to be entered into county-level or national competitions (the winning projects of Energy Sustainability are shown in the Appendix). Students must clearly introduce and demonstrate their work and research results during the competition to respond to the judges' questions appropriately. The judges or peers all considered that the students' works have extraordinary creativity and innovative ideas. For example,

- Jc1-F1-Y: It is full of creativity. The idea of the ventilation ball generator is wonderful. (20150726 at National Science Exhibition)

- $\quad \mathrm{J}_{2}-\mathbf{F}_{1}-\mathbf{Y}_{6}$ : The parallel power generation of wind turbine and solar panel is highly completed and the idea is very creative. However, when there is no wind and no sun, we need to find a solution. (20170419 at County Science Fair)

- $\quad \mathrm{Je}_{1}-\mathrm{F}_{2}-\mathrm{Y}_{7}$ : The idea of transforming a hydroelectric generator into an ocean current power generator is a good example for others to follow. (20180723 at National Science Fair)

The positive feedback from teachers and judges made the students more interested in hands-on work and creative thinking. The students presented this creative outburst in their self-reports and feedback and were willing to share their project work and practices on various forms of generators with the other school students. For example,

- $\quad \mathbf{T}_{2}-\mathbf{R}_{1}-\mathbf{Y}_{5}$ : I was touched by the unintended idea of a ceiling fan generator, which could lead to a creative idea of a ventilation ball generator. It was a very creative and student-initiated project that gave the whole school a high level of environmental activism. (20160725 in Principal's Office)

- $\quad \mathrm{S}_{\mathrm{c} 2}-\mathrm{F}_{2}-\mathrm{Y}_{5}$ : The external judges also thought that our idea of combining ceiling fan coils and ventilation balls was excellent. The ability to assemble by hand is great, and the work is very creative. I felt a great sense of accomplishment. (20160718 in Makers Classroom) 
- $\quad \mathrm{S}_{\mathrm{A} 3}-\mathrm{F}_{1}-\mathrm{Y}_{6}$ : The students' approval was more important to me. The students praised our wind power and solar energy parallel power generation, and thought it was a perfect idea to present 24-hour green energy. (20170705 in Makers Classroom)

- $\quad \mathrm{S}_{\mathrm{B} 3}-\mathrm{F}_{1}-\mathrm{Y}_{7}$ : Our teacher took us to clean the beach and ... (I) thought of the Kuroshio tide of the Pacific Ocean and came up with the idea of ocean currents for power generation. The judges agreed with me and thought we were very creative (Figure 17). (20180718 at County Gymnasium)
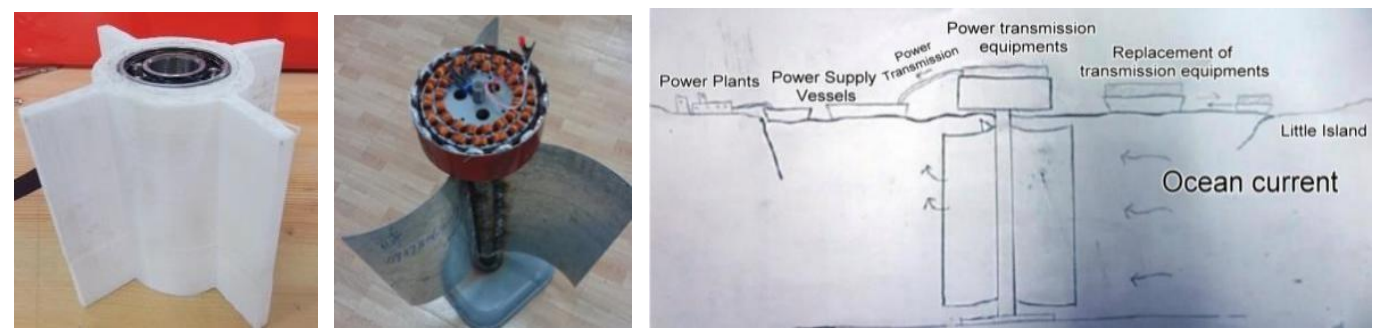

Figure 17. Students presented the idea of an ocean current generator by working on an upright hydroelectric generator (SD-A8- $\left.Y_{7} \& \mathrm{~S}_{D 1}-\mathrm{N}_{4}-\mathrm{Y}_{7}\right)$.

4-3 How engineering-centered PjBL enables rural students to make an impact and translate the concept of energy sustainability into action and enhance their learning attitude?

Students had a sense of honor for participating in the Makers Club because they can learn new technology and engineering techniques. In addition, the club students were low achievers, and they broke through themselves in the Implementation and Presentation phases, showing their other perspectives. After participating in the competition and winning awards, they have built up confidence and strengthened their positive attitude toward learning. Their peers looked at the performance of the club students with envy. Therefore, club teachers deliberately invited students in the original class to participate in completing projects by club students during the Implementation and Presentation phases. After returning to the original class, the club students can cooperate with their classmates, tolerate appreciation, and assist their peers in learning, especially in the study of sciences, and improve the whole class's attitude toward learning and even school.

\subsubsection{Implementation phase}

Invite the original class peers to provide ideas for the project and create an atmosphere for the whole class to participate project. Before the club students identify a topic to work on, the club teacher invites them to discuss it in their original classroom. This strategy created a friendly attitude toward science learning in the classroom, which led to active participation in activities and learning, and the project was deeply integrated into the concept of environmental sustainability (Figure 16). For example,

- $\quad \mathbf{P}_{5}-\mathbf{I}_{2}-\mathbf{Y}_{5}$ : I borrowed the disassembly tools from my uncle for my classmates (in the Makers (lub) to use in the assembly of the ventilated ball generator. Later when my classmates got the golden award, I felt a sense of accomplishment that helped and paid more attention to the energy issue. (20160621 at Makers Classroom)

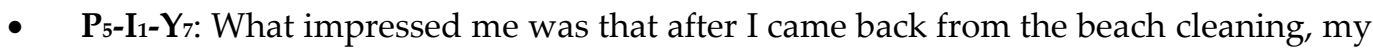
classmates drew the idea of ocean current power generation, and I also offered my opinion on power transmission, which was later made by simulating hydroelectric power generation, which was really impressive. (20180520 in Makers Classroom)

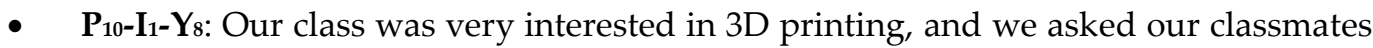
(in the Makers Club) to print it for us after class. 3D printing is really awesome. My classmates made 3D wind turbines. I contributed the idea as well. (20190526 in Makers Classroom) 


\subsubsection{Presentation phase}

Students in the club promote the concept of energy sustainability, teachers and students growing together to turn the concepts into action. Each year, the club teachers and the school administration arranged the presentation for each group to present their work at the school. The group members were required to present and explain their project work. All school students were encouraged to visit or operate on the products during class time and provided suggestions and ideas to the club students. Therefore, the club teachers used the lunch break and club time to train the group members' presentation skills. During this phase, students were assigned tasks and roles and were given the opportunity to make oral presentations. The teachers guided the Makers Club students to use the momentum of their project presentations to promote the idea of energy sustainability and love for the earth, which was expected to create a school-wide reflection on the importance of environmental sustainability and translate it into action (Figure 18). For example,
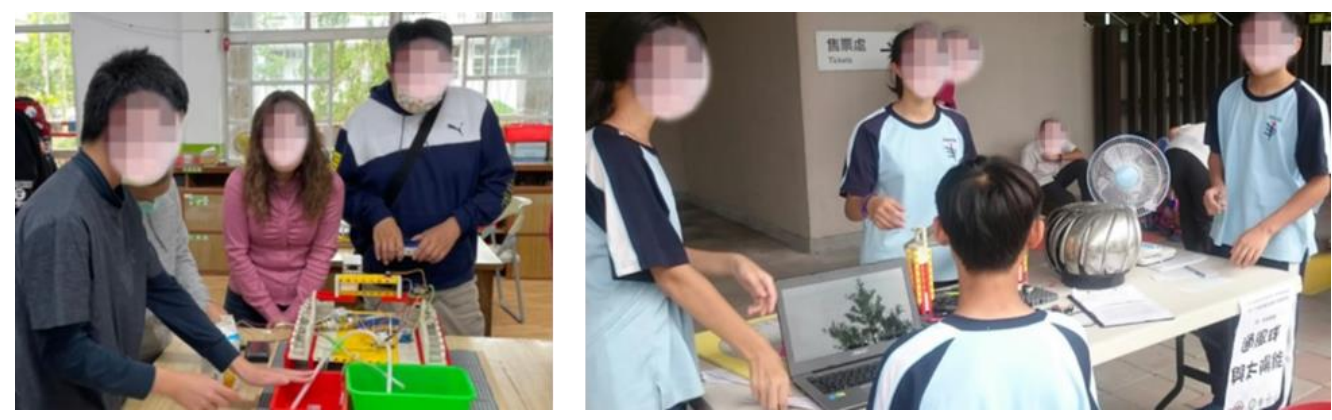

Figure 18. Inviting teachers and peers from the original class to provide ideas for topics to create a participatory atmosphere for the whole class ( $\left.\mathrm{S}_{\mathrm{B}}-\mathrm{A}_{7}-\mathrm{Y}_{7} \& \mathrm{~S}_{\mathrm{C}}-\mathrm{A}_{8}-\mathrm{Y}_{5}\right)$.

- $\mathrm{S}_{\mathrm{A} 2}-\mathrm{F}_{1}-\mathrm{Y}_{5}: \mathrm{Tzu}$ Chi often comes to our school to advocate environmental protection. So our group uses environmental concepts to explain our work, and we have received a good response (from judges). Because global warming ... green energy are important issues. (20160711 in Makers Classroom)

- $\quad \mathbf{P}_{3}-\mathbf{I}_{2}-\mathbf{Y}_{5:}$ I operated the ventilated ball generator. It was cool! We did a test, and the result showed it only made a $10 \mathrm{~W}$ bulb slightly brighter. I think it's essential to save water and electricity; the electricity generated by such a big generator is minimal. (20160513 in Makers Classroom)

- $\mathbf{T}_{3}-\mathrm{O}_{1}-\mathbf{Y}_{6}$ : I think that the students' awareness of environmental sustainability has grown tremendously. Whenever related topics were discussed in class, everyone was eager to share. I also observed that many classes have implemented recycling and reuse of plastic bags, which is related to our promotion of green energy demonstration. (20170802 in Academic Affairs Office)

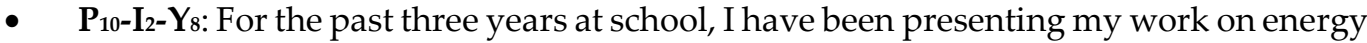
sustainability, providing us with many opportunities to practice. From saving water and electricity in our daily lives, to recycling and waste reduction, to the idea of caring for the countryside and marine conservation. The teachers and guests outside felt that we had a different temperament. (20190809 in the Office of Academic Affairs)

\subsubsection{Students in the Makers Club can collaborate and help their peers to learn}

Engineering-centered PjBL encouraged club students to think proactively, worked hands-on on energy sustainability projects, and shared ideas with their peers. After the newspaper and media reported the award-winning project, the teachers and students were honored, and the learning atmosphere of environmental education was strengthened in the students' minds. Although the number of students participating in the club was small—only 15 students per year, they had school-wide influence. It was surprising 
that not only the club students gained confidence in their engineering and science accomplishments after experiencing engineering learning and participating in competitions related to the energy sustainability topic, but they also returned to the classroom as senior students to help teachers enrich their teaching and increase student-teacher learning interactions. The Makers Club created a positive attitude and atmosphere for peer learning. For example,

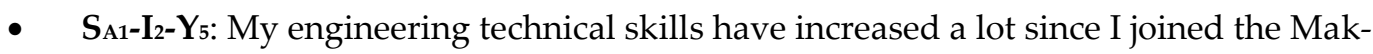
ers Club. The teacher would use some building blocks in the class, such as assembling blocks into a car, making a pulley set, making a lever, and I became more energetic. [When I returned to my original class,] I become more earnest in my science learning, and my classmates would ask me to teach them. (20160221 in Makers Classroom)

- $\mathbf{S}_{\mathrm{A} 1}-\mathrm{F}_{2}-\mathrm{Y}_{6}$ : I think the most influential thing for me was the competition, it made me practice and think all the time; we would simulate how the judges would ask and how we would answer. After I learned more, I was not afraid to discuss and interact with my classmates in class. (20170803 in Makers Classroom)

- $\quad$ P8-1- $_{-1} \mathbf{Y}_{6}$ : The students (who joined the Makers Club) with lower grades than me seemed to be more aggressive, so I changed my learning attitude and took the exams more seriously, ... fearing that I would lose to the students who participated in the hands-on work. (20170523 in Makers Classroom)

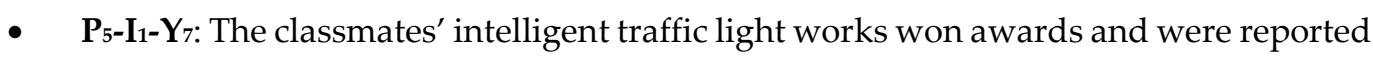
in the newspaper (Figure 19). We feel that they had become more confident, and we were all proud of them, and we became more serious in our studies. (20180520 in Makers Classroom)

\section{Production of intelligent traffic lights to solve the problem of standby energy consumption when there is no vehicle at the red light in the rural areas}

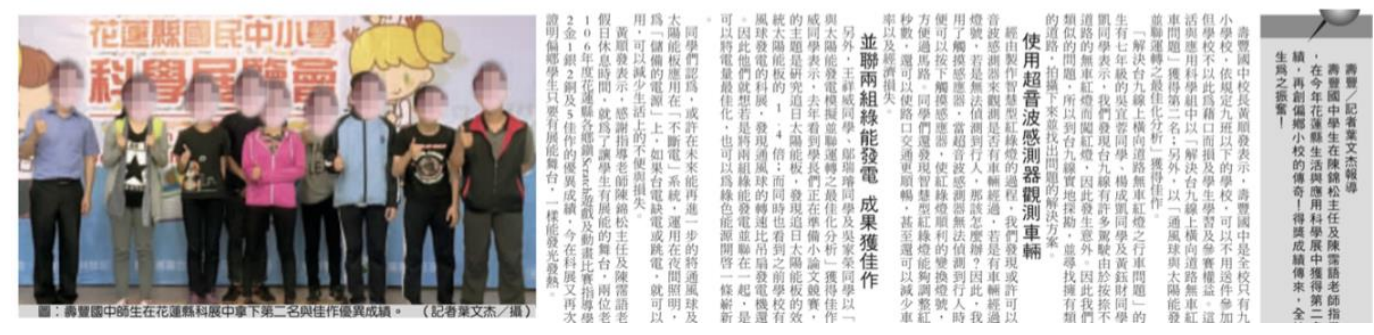

Figure 19. Students' environmental sustainability project won an award and was covered by the press, deepening students' ideas of environmental sustainability ( $\left.\mathrm{S}_{\mathrm{B}}-\mathrm{A}_{11}-\mathrm{Y}_{7}\right)$.

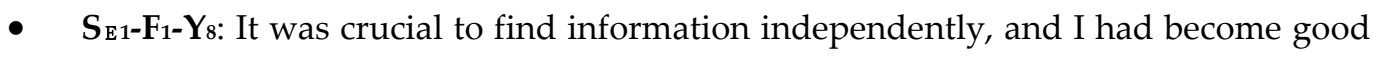
at thinking about questions. This is the fastest way to make myself better, and I am not afraid to ask questions to teachers. My classmates also believe I have improved, and it feels good to learn together. (20180805 in the Makers Classroom) 


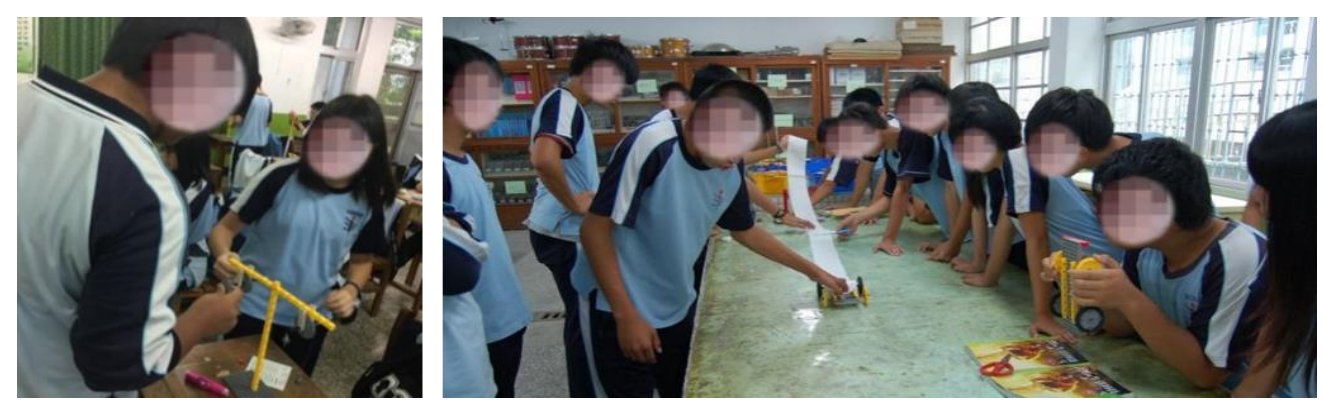

Figure 20. Makers Club was students' free-thinking space. Students made teaching aids by themselves. $\left(\mathrm{S}_{\mathrm{E}}-\mathrm{A}_{6}-\mathrm{Y}_{8}\right)$.

\section{Conclusions and Discussion}

The mathematics and science teachers in Longevity Junior High School have been supporting students to practice and demonstrate the results of sustainable energy through projects for a long time. In the 2015 school year, the students created a wind turbine with a wind ball to demonstrate how engineering-centered PjBL solves problems in our daily lives, emphasizing the importance of engineering applications and awareness [42]. The parallel power generation installation of wind power and solar panels was completed in the 2016 school year, which embodies the engineering value of energy technology through the engineering connection of energy-saving and solar energy [43]. In the 2017 school year, the vertical rotating structure of a ceiling fan generator was applied to hydroelectric power generation and even simulated the idea of ocean currents for power generation. In the 2018 school year, the 3D technology was applied to print a lightweight wind turbine, echoing the "new industrial revolution image " constructed by Anderson [44].

These fruitful results came from the teachers' long-term implementation of the engineering-centered PjBL of sustainable energy, where they found strengths for rural students who had previously failed in academic achievement, created positive, successful experiences, and ultimately even changed their perceptions that they must have failed in academic achievement. The results of this study echoed the importance of successful experience for intellectual inability students [32]. The club teachers designed, reflected, and revised the curriculum. The principles and effects of curriculum development are summarized below according to the five phases of PjBL. However, such experiences do not apply in urban schools, where the emphasis is generally on academic achievement.

\subsection{Creativity and Engineering Technical Skill are Mainly Emphasized in the Preparation and Implementation Phases}

Most teachers in this study are not engineering professionals, but they actively participated in professional development programs of Arduino and 3D printing to increase their engineering technical skills and provide the latest technology to their students, which is the root of innovation. In addition, one important responsibility for teachers was finding funding and resources. For rural students, the challenge of research failure is not at the top of their minds, but money issues are. Implementing projects with creativity costs a lot of money. Teachers need to apply for more project funding in order to buy equipment, tools, and materials. Sometimes, teachers and students need to be creative with local materials or borrow these resources from their relatives, friends, or NGOs to help their learning. Similar difficulties are not encountered in urban schools with professional teachers and abundant resources.

Student mentorship was the other critical factor. The seniors, students who participated in the PjBL and Maker Club in previous years, not only provided a role model for the younger students to follow but also passed their scientific principles, competition experience, and engineering technical skills. The teachers and students found real problems in their daily life (e.g., disassembled an old rebuilding fan, clean beach, and the vehicles stopped by the traffic light on the rural road) and were not afraid of difficulties of trial and failure. Students and teachers kept doing practical work and testing their ideas in an 
authentic, real-world context, from which they found the gap between theory and reality and generated creativity to overcome the problems.

\subsection{Atmosphere of Actions for Green Energy Sustainability and Good Learning Attitude are Chiefly Cultivated in the Presentation, Competition, and Feedback Phases}

Teachers took the initiative to invite the original class and all school students to participate in the club students' project work, including practical exercises and feedback. This strategy allowed the club students to display and even appreciate their work rather than their academic achievement. After practicing in front of their peers, the club students' presentation skills and confidence increased. The invitation of the original class students to advise and act as a judge not only made them feel valued but also gave them a sense of participation in the project work. After the club students' projects had won awards, students in the entire school felt their cooperative works received the honor, thus enhancing the club and all school students turn the concepts of environmental protection into actions.

Students who participated in the Makers Club returned to their original classes and took the initiative to assist their peers in their learning, creating an atmosphere of sustainable energy learning and inspiring their peers' attitude and commitment to learning. In turn, the students' practical engineering technical skills were enhanced, which assisted the teachers in their original classes and enriches the course content with students' work. With the positive comparison and motivation among students, the school has developed a good learning atmosphere, which has enhanced academic learning, CAP scores and even increased the enrollment rate of the school [12].

The school took the initiative to plan the exhibition space and co-organized the technical university's hydroelectric energy competition. These strategies provided students with a variety of opportunities to think and observe diversely. The principal (T2) played a critical role. He was involved in students' training and participated in the teacher professional development programs, understood the needs of teachers and students, and showed the school's respect for students and their work.

\subsection{Integrating Ethics, Empathy, and Caring into Energy Education toward more Contributions} to Sustainability

Gunckel and Tolbert [45] argued that a hands-on school curriculum should integrate ethics, empathy, and caring dimensions into science and engineering education and needs to be lived out, with a commitment to the harmony of science and engineering with the social humanities. Therefore, in addition to the principles of implementing PjBL, the teachers in this study recognized that caring is the core of scientific literacy, and the students' project work continues to be presented in this context. Students used engineering practice as the basis for their project work, producing and exploring projects based on sustainable energy and contributing to the concept of ecological sustainability. In addition to energy sustainability, the students developed a variety of ideas on environmental sustainability, such as the problem of wasting energy by waiting for motorcycles at red lights on roads in rural areas, the issue of overfishing of ocean sunfish for sustainable development of the ocean, the problem of heat dissipation in non-toxic greenhouse agriculture in remote areas, and the design of a rainwater tanks sprinkler system to save water resources. This study's teaching plan and project work provided other schools with advanced teaching applications at no cost over the years. 


\section{Appendix}

The award-winning products in the Energy Sustainability Projects during the 2015 2018 school years

\begin{tabular}{|c|c|c|c|c|}
\hline School year & Group & Type of competition & Title of the project & Rank \\
\hline \multirow[t]{2}{*}{2015} & C & $\begin{array}{c}\text { The } 55^{\text {th }} \text { science fair at the na- } \\
\text { tional level }\end{array}$ & $\begin{array}{l}\text { An analysis of the optimiza- } \\
\text { tion of the electricity genera- } \\
\text { tion by a ventilation ball }\end{array}$ & $\begin{array}{c}\text { The } 1^{\text {st }} \text { place at the } \\
\text { county level; excellence } \\
\text { award at the national } \\
\text { level }\end{array}$ \\
\hline & $\mathrm{D}$ & $\begin{array}{l}\text { The 1st creativity science project } \\
\text { competition at the national level }\end{array}$ & $\begin{array}{c}\text { Solar greenhouse cooling sys- } \\
\text { tem }\end{array}$ & Gold creativity award \\
\hline \multirow{3}{*}{2016} & A & $\begin{array}{l}\text { Short essay contest at the na- } \\
\text { tional level }\end{array}$ & $\begin{array}{c}\text { An analysis of the optimiza- } \\
\text { tion of the electricity genera- } \\
\text { tion by solar panel }\end{array}$ & Silver creativity award \\
\hline & A & $\begin{array}{c}\text { The } 56^{\text {th }} \text { science fair at the na- } \\
\text { tional level }\end{array}$ & $\begin{array}{c}\text { An analysis of the optimiza- } \\
\text { tion of the electricity genera- } \\
\text { tion by rerating solar panel }\end{array}$ & Excellence award \\
\hline & E & $\begin{array}{l}\text { National Energy Innovation } \\
\text { Competition }\end{array}$ & $\begin{array}{l}\text { Analysis of parallel power } \\
\text { generation between ventila- } \\
\text { tion ball and solar panel }\end{array}$ & Bronze creativity award \\
\hline \multirow[b]{2}{*}{2017} & B & $\begin{array}{c}\text { The } 57^{\text {th }} \text { science fair at the na- } \\
\text { tional level }\end{array}$ & $\begin{array}{l}\text { Solve the traffic problem of no } \\
\text { vehicles but a red light on the } \\
\text { crossroads in the rural area }\end{array}$ & The $2^{\text {nd }}$ place \\
\hline & $\mathrm{D}$ & $\begin{array}{c}\text { The 57th science fair at the na- } \\
\text { tional level }\end{array}$ & $\begin{array}{c}\text { An analysis of the optimiza- } \\
\text { tion of the electricity genera- } \\
\text { tion by expandable multifunc- } \\
\text { tional generators }\end{array}$ & $\begin{array}{c}\text { The } 1^{\text {st }} \text { place at the } \\
\text { county level; spirit of in- } \\
\text { quiry award at the na- } \\
\text { tional level }\end{array}$ \\
\hline \multirow{4}{*}{2018} & A & $\begin{array}{l}\text { Short essay contest at the na- } \\
\text { tional level }\end{array}$ & $\begin{array}{l}\text { The beauty and sorrow of } \\
\text { ocean sunfish }\end{array}$ & Gold creativity award \\
\hline & B & $\begin{array}{c}\text { The } 58^{\text {th }} \text { science fair at the na- } \\
\text { tional level }\end{array}$ & $\begin{array}{c}\text { An analysis of the optimiza- } \\
\text { tion of the expandable 3D } \\
\text { printing wind power genera- } \\
\text { tor }\end{array}$ & The $2^{\text {nd }}$ place \\
\hline & $\mathrm{C}$ & $\begin{array}{c}\text { Exhibition for young inventors } \\
\text { at the national level }\end{array}$ & $\begin{array}{c}\text { Rainwater tanks automatic } \\
\text { sprinkler system }\end{array}$ & $\begin{array}{c}\text { The } 3^{\text {rd }} \text { place at the } \\
\text { county level; Bronze cre- } \\
\text { ativity award at the na- } \\
\text { tional level }\end{array}$ \\
\hline & $\mathrm{D}$ & $\begin{array}{l}\text { Short essay contest at the na- } \\
\text { tional level }\end{array}$ & $\begin{array}{c}\text { 3D printing wind power gen- } \\
\text { erator }\end{array}$ & Gold creativity award \\
\hline
\end{tabular}




\section{References}

1. Trinidad, S., Sharplin, E., Ledger, S., Broadley, T. Connecting for innovation: Four universities collaboratively preparing preservice teachers to teach in rural and remote Western Australia. J. Res. Rural Educ. 2014, 29(2), 1-13.

2. Her, R. Dharma Master Cheng Yen's Environmental View of Life and The Development of Tzu Chi's Environmental Mission. Cambridge Scholars Publishing Humankind and Nature, 2014, pp.110-142.

3. Hsiao, H. Y., Hsu, H. T., Boudreaux, D., Ting, A. Global grassroots green movement driven by Tzu Chi Foundation's recycling volunteers: A multifaceted model of environmental sustainability with transformative social changes. Soc. Work Sustain. Asia. Routledge, 2019, pp. 61-82.

4. Shih, D. Y., Tsai, Y. M. (2012). Environmental humanity and sustainability in Tzu Chi's charity movements. Tzu-Chi Univ. J. Hum. Soc. Sci. 2012, (14), 67-100.

5. Kweku, D. W., Bismark, O., Maxwell, A., Desmond, K. A., Danso, K. B., Oti-Mensah, E. A., Adormaa, B. B. Greenhouse effect: Greenhouse gases and their impact on global warming. J. Sci Res Rep. 2017, 1-9.

6. Pacheco, L., Ningsu, L., Pujol, T., Gonzalez, J. R., Ferrer, I. Impactful engineering education through sustainable energy collaborations with public and private entities. Int. J. Sustain. High. Educ. 2019, 20(2), 393-407.

7. McIver, L., Kim, R., Woodward, A., Hales, S., Spickett, J., Katscherian, D., ... Ebi, K. L. Health impacts of climate change in Pacific Island countries: A regional assessment of vulnerabilities and adaptation priorities. Environ. Health Perspect. 2016, 124(11), 1707-1714.

8. Pacifici, M., Foden, W. B., Visconti, P., Watson, J. E., Butchart, S. H., Kovacs, K. M., ... Rondinini, C. Assessing species vulnerability to climate change. Nat. Clim. Chang. 2015, 5(3), 215-224.

9. Ministry of Education in Taiwan. Curriculum guidelines of 12-year basic education General guidelines. 2014, Retrieved June 10, 2019, from [CrossRef]

10. Coronado, J. M., Moyano, A., Romero, V., Ruiz, R., Rodríguez, J. Student long-term perception of project-based learning in civil engineering education: An 18-year ex-post assessment. Sustainability. 2021, 13(4), 1949. [CrossRef]

11. Mills, J. E., Treagust, D. F. Engineering education-Is problem-based or project-based learning the answer. Australas. J. Educ. Technol. 2003, 3(2), 2-16.

12. Chen, C. S., Lin, J. W. A practical action research study of the impact of maker-centered STEM-PjBL on a rural middle school in Taiwan. Int. J. Sci. Math. Educ. 2019, 17(1), 85-108.

13. Krajcik, J. S., Czerniak, C. M. Teaching science in elementary and middle school: A project-based learning approach. 5th ed.; Routledge: London, England, 2018.

14. Martin, L. The promise of the maker movement for education. J. Pre-College Eng. Educ. 2015, 5(1), Article 4, 30-39.

15. Bevan, B. The promise and the promises of making in science education. Stud. Sci. Educ. 2017, 53(1), 75-103.

16. Huang, N. T. N., Chiu, L. J., Hong, J. C. Relationship among students' problem-solving attitude, perceived value, behavioral attitude, and intention to participate in a science and technology contest. Int. J. Sci. Math. Educ. 2016, 14(8), $1419-1435$.

17. Suprapto, N., Liu, W. Y., Ku, C. H. The implementation of multiple intelligence in (science) classroom: From empirical into critical. Pedagogika. 2017, 126(2). 214-227.

18. Hoople, G. D., Chen, D. A., Lord, S. M., Gelles, L. A., Bilow, F., \& Mejia, J. A. An integrated approach to energy education in engineering. Sustainability. 2020, 12(21), 9145. [CrossRef]

19. Tytler, R., \& Osborne, J. Student attitudes and aspirations towards science. In B. Fraser, K., Tobin, C. J. McRobbie (Eds.). Second international handbook of science education. Springer : New York, USA. 2012; pp. 597-625.

20. Clapp, E. P., Jimenez, R. L. Implementing STEAM in maker-centered learning. Psychol. Aesthet. Creat. Arts. 2016, 10(4), 481-491.

21. Glăveanu, V. P. Educating which creativity? Thinking Skills and Creativity. 2018, 27, 25-32.

22. Kokotsaki, D., Menzies, V., Wiggins, A. Project-based learning: A review of the literature. Improving schools. 2016, 19(3), 267-277.

23. Vogler, J. S., Thompson, P., Davis, D. W., Mayfield, B. E., Finley, P. M., \& Yasseri, D. The hard work of soft skills: augmenting the project-based learning experience with interdisciplinary teamwork. Instr. Sci. 2018, 46, 457-488. [CrossRef] 
24. Balaji, K. V. A., Somashekar, P. A Comparative Study of Soft Skills Among Engineers. IUP J. Soft Skills. $2009,3$.

25. Khandakar, A., Chowdhury, M. E. H., Gonzales Jr, A., Pedro, S., Touati, F., Emadi, N. A., Ayari, M. A. Case study to analyze the impact of multi-course project-based learning approach on education for sustainable development. 2020, Sustainability. 12(2), 480. [CrossRef]

26. Paretti, M. C. Towards an Integrated Assessment Framework: using activity theory to understand, evaluate, and enhance programmatic assessment in Integrated Content and Language Learning. J. Acad Writ. 2013, 3(1), 95-119.

27. Hennessey, B. A., \& Amabile, T. M. Creativity. Annu. Rev. Psychol. 2010, 61, 569-598.

28. Epstein, R., Schmidt, S. M., \& Warfel, R. Measuring and training creativity competencies: Validation of a new test. Creat Res J. 2008, 20(1), 7-12.

29. Hocevar, D., Bachelor, P. A taxonomy and critique of measurements used in the study of creativity. In Glover, J. A., Ronning, R. R., Reynolds, C., (Eds.). Handbook of creativity. MA: Springer, Boston, USA,1989, 53-75.

30. Yang, K. K., Lee, L., Hong, Z. R., \& Lin, H. S. Investigation of effective strategies for developing creative science thinking. Int. J. Sci. Educ. 2016, 38(13), 2133-2151.

31. Myers, D. G. Social psychology (4th ed.). NY: McGraw-Hill, New York, USA, 1993.

32. Fishbein, M., Ajzen, I. Belief, attitude, intention and behaviour: An introduction to theory and research. Reading, MA: AddisonWesley, Boston,USA, 1975. [CrossRef]

33. Crano, W. D., Prislin, R. Attitudes and persuasion. Annu. Rev. Psychol. 2007, 57, 345-374.

34. Juan, A., Hannan, S., Namome, C. I believe I can do science: Self-efficacy and science achievement of Grade 9 students in South Africa. S. Afr. J. Sci. 2018, 114(7-8), 48-54.

35. Lee, S. What Motivates and Engages Students in the Education Process--An Examination of Qatari Students' Mindset and Attitudes toward Going to School, Learning, and Future Aspirations. J. Educ. Learn. 2016, 5(3), 220-235.

36. Tyson, K. Weighing in: Elementary-age students and the debate on attitudes toward school among Black students. Soc forces. 2002, 80(4), 1157-1189.

37. Grundy, S. Three modes of action research. Curric. Perspect. 1982, 2(3), 23-34.

38. Gummesson, E. Qualitative methods in management research; Sage: Thousand Oaks, CA, USA, 2000.

39. National Science and Technology Museum. Energy conservation \& technology innovation competition. 2014. Retrieved June 14, 2019, from [CrossRef]

40. Han, S. Korean students' attitudes toward STEM project-based learning and major selection. Educ. Sci. Theory Pract. 2017, 17(2), 529-548.

41. United Nations General Assembly: Transforming Our World: The 2030 Agenda for Sustainable Development. Draft resolution referred to the United Nations summit for the adoption of the post-2015 development agenda by the General Assembly at its sixty-ninth session. 2015, Retrieved July 28, 2021, from [CrossRef]

42. Shahali, E. H. M., Halim, L., Rasul, M. S., Osman, K., Zulkifeli, M. A. (2016). STEM learning through engineering design: Impact on middle secondary students' interest towards STEM. Eurasia J. Math. Sci. Technol. Educ. 2016, 13(5), 1189-1211.

43. Fujihira, K., Osuka, K.. An educational methodology for sustainable development. In 2009 ICCAS-SICE. 2009, August (pp. 42664271). IEEE.

44. Anderson, C. Makers: The new industrial revolution. 2014, Crown Business: New York, USA.

45. Gunckel, K. L., Tolbert, S. The imperative to move toward a dimension of care in engineering education. J. Res. Sci. Teach. 2018, 55(7), 938-961. 